\title{
Chemical preparations, crystal data for monophosphates and condensed Phosphates associated to manganese and IR studies of their anions
}

\author{
Hamza Marouani ${ }^{1}$, Rachida Oubouaza ${ }^{1}$, Soufiane Zerraf ${ }^{1}$, Ali Ouasri ${ }^{2}$, MalikaTridane ${ }^{1,3}$ \\ And Said Belaaouad ${ }^{1}$ \\ ${ }^{1}$ Laboratory of Chemistry-Physics of Materials, Faculty of Sciences Ben M'Sik B. P. 7955, Hassan II University \\ of Casablanca, Morocco \\ ${ }^{2}$ Centre Régional des métiers d'éducation et de formation Rabat, Maroc. \\ ${ }^{3}$ Centre Régional des métiers d'éducation et de formation, Bd Bir Anzarane Casablanca Maroc.
}

\begin{abstract}
The monophosphates and condensed phosphates associated with manganese, which are the subject of this article are an important part of phosphate chemistry and have been the subject of numerous studies and applications in many areas of Materials research and industry. In order to collect the unit cell parameters of these compounds, to establish a database of formulas existing up to now and to get an idea of the ease and difficulty of their preparation, we are concentrating the current research on chemical preparations, crystal data and IR studies for condensed phosphates and monophosphates. This work presents the chemical preparations, the main crystallographic data for manganese associated condensed phosphates and monophosphates, and the characterization by infrared vibration spectrometry for anions $\mathrm{PO}_{3}{ }^{-}, \mathrm{PO}_{4}{ }^{3-}, \mathrm{P}_{2} \mathrm{O}_{7}{ }^{4-}$, $\mathrm{P}_{3} \mathrm{O}_{9}{ }^{3-}, \mathrm{P}_{4} \mathrm{O}_{12}{ }^{4-}, \mathrm{P}_{6} \mathrm{O}_{18}{ }^{6-}$ and $\mathrm{P}_{10} \mathrm{O}_{30}{ }^{10-}$ in different compounds
\end{abstract}

Keywords: Engineering Techniques, Chemical preparation, chemical analyses, crystallographic characterization, infrared vibration spectrometry, monophosphates, condensed Phosphates manganese

\section{INTRODUCTION}

Manganese is a heavy metal, part of the transition elements. Silvery, hard and brittle, it has magnetic properties [1]. The metal is chemically reactive: it oxidizes in the air but it does not react with water under normal conditions [2]. Its electronegativity leads it to form ionic bonds with oxides, hydroxides and carbonates. It thus forms unstable complexes (oxides, silicates, carbonates), most of which are less soluble than its hydroxides [3]. Manganese has common properties with cobalt and iron and the similarities between their respective behaviors are numerous [4].

The choice of manganese study associated with condensed phosphates and mono phosphates is justified by the properties physical-chemical that presents this element. Phosphate chemistry is a vast field of research in which a large number of laboratories around the world are engaged. Research work on these compounds, far from being exhausted, has on the contrary intensified particularly during the last thirty years. The main reasons for this intensification are Phosphate chemistry is a vast field of research in which a large number of laboratories around the world are engaged. Research work on these compounds, far from being exhausted, has on the contrary intensified particularly during the last thirty years. The main reasons for this intensification are the discovery and growth of new methods of synthesis of phosphate-based compounds, the development of new indexing and structural resolution programs related to structural characterization techniques. The search for materials likely to have particular interesting properties and which can therefore be used in the fields applied. The present work describes the chemical preparations and reports crystal data for condensed phosphates and monophosphates associated to manganese and IR vibration spectrometry studies of their anions.

\section{ELABORATION AND CRYSTAL DATA}

The basic element of the constitution of all the phosphoric anions is the entity that we will designate most often under the name of $\mathrm{PO}_{4}$ tetrahedron or $\mathrm{PO}_{4}$ group [5]. This entity is constituted by a central atom of phosphorus $(\mathrm{P})$ surrounded by four oxygen atoms building around it an almost regular tetrahedron. A phosphoric anion consists of one, (case of monophosphates), or several of these entities pooling vertices (case of condensed phosphates).

We can first divide all the phosphates into two categories: monophosphates and condensed phosphates and give two strict definitions to differentiate them: monophosphate is a salt whose anion consists of an isolated $\mathrm{PO}_{4}$ group and condensed phosphate is a salt whose anionic entity formed of several $\mathrm{PO}_{4}$ tetrahedra sharing vertices, thus contains one or more $\mathrm{P}-\mathrm{O}-\mathrm{P}$ bonds. 
Hamza Marouani et al., International Journal of Emerging Trends in Engineering Research, 8(7), July 2020, 4784 - 4798

\section{INFRARED VIBRATION SPECTROMETRY}

Spectra were recorded in the range $4000-400 \mathrm{~cm}^{-1}$, with a Perkin-Elmer IR 983G spectrophotometer, using samples dispersed in spectroscopically pure $\mathrm{KBr}$ pellets.

\subsection{Monophosphates $\mathrm{PO}_{4}{ }^{3-}$}

On the first of these families whose anionic entity is simple, since formed of an isolated $\mathrm{PO}_{4}$ group, no comment is necessary. We can simply add that the compounds of this family, long known as orthophosphates, are now known under the name of monophosphates.

In this part we present the synthesis of monophosphate associated with manganese by the various synthetic methods: synthesis by solid state diffusion, synthesis hydrothermal or synthesis by soft chemistry, structural characterization thus studies by IR vibration spectrometry of their anions. We have been able to isolate and characterize several phosphates of $\mathrm{Mn}-\mathrm{PO}_{4}$ type as an example: $\mathrm{MnHPO}_{4} \cdot \mathrm{H}_{2} \mathrm{O}, \mathrm{RbMnPO}_{4}$, $\mathrm{NH}_{4} \mathrm{MnPO}_{4} \cdot \mathrm{H}_{2} \mathrm{O}, \mathrm{NaMnPO}_{4}, \mathrm{Na}_{4} \mathrm{Mn}_{3}\left(\mathrm{PO}_{4}\right)_{2}\left(\mathrm{P}_{2} \mathrm{O}_{7}\right)$, $\mathrm{Mn}_{0.5} \mathrm{Co}_{0.5} \mathrm{NH}_{4} \mathrm{PO}_{4} \cdot 2 \mathrm{H}_{2} \mathrm{O}, \mathrm{Mn}_{3}\left(\mathrm{PO}_{4}\right)_{2} \cdot 3 \mathrm{H}_{2} \mathrm{O}, \mathrm{Mn}_{3}\left(\mathrm{PO}_{4}\right)_{2}$, $\mathrm{LiMnPO}_{4}, \mathrm{Li}_{3} \mathrm{~V}_{2}-\mathrm{xMnx}\left(\mathrm{PO}_{4}\right)_{3}, \mathrm{KMnPO}_{4} \cdot \mathrm{H}_{2} \mathrm{O}, \mathrm{CsMnPO}_{4}$, $\mathrm{RbMnPO}_{4}, \mathrm{Ca}_{1,54} \mathrm{Mn}_{1,46} \mathrm{Fe}\left(\mathrm{PO}_{4}\right)_{3}$.

\subsection{Sample preparation}

\section{1. $\mathrm{MnHPO}_{4} \cdot \mathrm{H}_{2} \mathrm{O}$}

The $\mathrm{MnHPO}_{4} \cdot \mathrm{H}_{2} \mathrm{O}$ [6] compound was prepared by solution precipitation method using Mn (complexometric), $99.99 \%$, Merck) and phosphoric acid $\left(86.4 \% \mathrm{w} / \mathrm{w} \mathrm{H}_{3} \mathrm{PO}_{4}\right.$ Merck) as starting materials. In typical procedure, about $0.5 \mathrm{~g}$ of $\mathrm{Mn}$ (c) was dissolved in $5 \mathrm{~mL}$ of $1 \mathrm{MH}_{3} \mathrm{PO}_{4}$. The resulting solution was stirred until $\mathrm{H}_{2}(\mathrm{~g})$ was completely evolved and the green gray precipitates were obtained (about 10min). The prepared solid was filtered by suction pump, washed with water and dried in air.

\section{3 $\mathrm{RbMnPO}_{4}$}

A powder sample of $\mathrm{RbMnPO}_{4}$ [7] was prepared by direct solid state reaction from stoichiometric mixtures of $\mathrm{Rb}_{2} \mathrm{CO}_{3}$, $\mathrm{MnO}$, and $\left(\mathrm{NH}_{4}\right) \mathrm{H}_{2} \mathrm{PO}_{4}$ powders as previously reported.6 The mixture was fired at $500{ }^{\circ} \mathrm{C}$ in argon atmosphere for 2 days, and then the mixture was ground, pelletized, and heated at $800{ }^{\circ} \mathrm{C}$ for $36 \mathrm{~h}$ and at $1050{ }^{\circ} \mathrm{C}$ for $24 \mathrm{~h}$ with intermediate grindings to ensure a total reaction. The resulting powder sample is very fine and light beige. Sample purity was checked by laboratory powder X-ray diffraction.

\section{$3.4 \mathrm{NH}_{4} \mathrm{MnPO}_{4} \cdot \mathrm{H}_{2} \mathrm{O}$}

$\mathrm{NH}_{4} \mathrm{MnPO}_{4} \cdot \mathrm{H}_{2} \mathrm{O}$ [8] micro-nanostructures, $\mathrm{M}_{1}-\mathrm{M}_{3}$ and $\mathrm{M}_{6}$ : Manganous chloride $\left(\mathrm{MnCl}_{2} \cdot 4 \mathrm{H}_{2} \mathrm{O}\right)$ and ammonium phosphate $\left(\left(\mathrm{NH}_{4}\right)_{3} \mathrm{PO}_{4} \cdot 3 \mathrm{H}_{2} \mathrm{O}\right)$ were used as manganese cation and phosphate anion precursors, respectively. Typically, $3.0 \mathrm{~g}$ of ammonium chloride and $0.2 \mathrm{~g}$ of ammonium phosphate was added to a beaker and then $40 \mathrm{~mL}$ ethylene glycol $\left(\mathrm{M}_{1}\right)$ or $20 \mathrm{~mL}$ water and $20 \mathrm{~mL}$ ethylene glycol $\left(\mathrm{M}_{2}\right)$, or $20 \mathrm{~mL}$ water and $20 \mathrm{~mL}$ glycerol $\left(\mathrm{M}_{3}\right)$, or $20 \mathrm{~mL}$ water and $20 \mathrm{~mL}$ polyethylene glycol $\left(\mathrm{M}_{6}\right)$ was added. Mixture was stirred at room temperature until solid were completely dissolved then $0.2 \mathrm{~g} \mathrm{MnCl}_{2} \cdot 4 \mathrm{H}_{2} \mathrm{O}$ was added to mixed solution and vigorous magnetic stirring at room temperature for $12 \mathrm{~h}$. The obtained homogeneous white precipitates were washed with deionized water and ethanol several times and dried.

$\mathrm{NH}_{4} \mathrm{MnPO}_{4} \cdot \mathrm{H}_{2} \mathrm{O}$ micro-nanostructures, $\mathrm{M}_{4}-\mathrm{M}_{5}$ : $3.0 \mathrm{~g}$ of ammonium phosphate was added to a beaker and then $80 \mathrm{~mL}$ ethylene glycol $\left(\mathrm{M}_{4}\right)$ or $40 \mathrm{~mL}$ ethylene glycol $\left(\mathrm{M}_{5}\right)$ was added. Mixture was stirred at room temperature until solid were completely dissolved. Then, $0.2 \mathrm{~g} \mathrm{MnCl}_{2} \cdot 4 \mathrm{H}_{2} \mathrm{O}$ was added to the mixed solution and vigorous magnetic stirring at room temperature for $12 \mathrm{~h}$. The subsequent synthesis procedure was the same as that described above.

\section{5 $\mathrm{NaMnPO}_{4} .3 \mathrm{H}_{2} \mathrm{O}$}

In a typical synthesis, $\mathrm{MnSO}_{4} \mathrm{H}_{2} \mathrm{O}(20.00 \mathrm{~g}), \mathrm{Na}_{3} \mathrm{PO}_{4} \cdot 12 \mathrm{H}_{2} \mathrm{O}$ (53.98g), and surfactant PEG (polyethylene glycol)-400 (2.0 $\mathrm{mL}$ ) were put in a mortar, and the mixture was fully ground by hand with a rubbing mallet for $40 \mathrm{~min}$. The grinding velocity was about 90 circles/ min, and the strength applied was moderate. The reactant mixture gradually became damp, and then a paste formed quickly. The reaction mixture was maintained at room temperature for $3 \mathrm{~h}$. The mixture was washed with water to remove soluble inorganic salts until $\mathrm{SO}_{4}{ }^{2-}$ ion could not be visually detected with $0.5 \mathrm{molL}^{-1} \mathrm{BaCl}_{2}$ solution. The solid was then washed with a small amount of anhydrous ethanol and dried at $70^{\circ} \mathrm{C}$ for $3 \mathrm{~h}$. The resulting material was subsequently determined to be the nanocrystalline $\mathrm{NaMnPO}_{4} 3 \mathrm{H}_{2} \mathrm{O}$ [9].

\section{6 $\mathrm{Na}_{4} \mathrm{Mn}_{3}\left(\mathrm{PO}_{4}\right)_{2}\left(\mathrm{P}_{2} \mathrm{O}_{7}\right)$}

The new phases $\mathrm{Na}_{4} \mathrm{Mn}_{3}\left(\mathrm{PO}_{4}\right)_{2}\left(\mathrm{P}_{2} \mathrm{O}_{7}\right)[\mathbf{1 0}]$ were also obtained as a microcrystalline powder by solid-state reaction, employing as precursors $\mathrm{Na}_{4} \mathrm{P}_{2} \mathrm{O}_{7}, \mathrm{MnCO}_{3}, \mathrm{Ni}\left(\mathrm{NO}_{3}\right)_{2} \cdot 6 \mathrm{H}_{2} \mathrm{O}$, and $\mathrm{NH}_{4} \mathrm{H}_{2} \mathrm{PO}_{4}$, in the same molar ratios used to obtain single crystals. The mixtures were heated at $300{ }^{\circ} \mathrm{C}$ in a porcelain crucible to decompose and remove the volatile species. Then accumulative treatments for $24 \mathrm{~h}$ each at $400,500,600$, and $700^{\circ} \mathrm{C}$ for manganese samples to $800^{\circ} \mathrm{C}$ in the case of the nickel sample were performed.

\section{7 $\mathrm{CsMnPO}_{4}$}

The sample of phosphate $\mathrm{CsMnPO}_{4}$ was synthesized by the co-precipitation method, using the procedure earlier applied for $\mathrm{CsMgPO}_{4}$ synthesis and described in [11]. The starting reagents for synthesis were $\mathrm{CsCl}, \mathrm{Mn}\left(\mathrm{CH}_{3} \mathrm{COO}\right)_{2} \cdot 4 \mathrm{H}_{2} \mathrm{O}$ and $\mathrm{NH}_{4} \mathrm{H}_{2} \mathrm{PO}_{4}$. The provenance and purity of the reagents used in this study are listed in table 1 . The purity of the starting 
Hamza Marouani et al., International Journal of Emerging Trends in Engineering Research, 8(7), July 2020, 4784 - 4798

$\mathrm{Mn}\left(\mathrm{CH}_{3} \mathrm{COO}\right)_{2} \cdot 4 \mathrm{H}_{2} \mathrm{O}$ is explained by the uncertainty in the $\mathrm{H}_{2} \mathrm{O}$ content in this chemical. That is why the manganese concentration in the solution taken for synthesis was confirmed gravimetrically.

\section{$3.8 \mathrm{Mn}_{3}\left(\mathrm{PO}_{4}\right)_{2}$}

A novel phase transparent light-yellow crystals of distorted octahedral shape with a maximum size of about $0.5 \mathrm{~mm}$ was grown under hydrothermal conditions. A mixture of $\mathrm{Mn}_{2} \mathrm{O}_{3}\left(\mathrm{NH}_{4}\right)_{3} \mathrm{PO}_{4}$ and $\mathrm{GaPO}_{4}$ in a weight ratio of 3:3:1 was placed in a titanium vessel with water and enclosed in a stainless steel bomb. A small amount of $\mathrm{B}_{2} \mathrm{O}_{3}(7 \%)$ was added to the starting material as a mineralize that allowed keeping the $\mathrm{pH}$ of the solution close to a neutral value. The reaction time at $\mathrm{T}=270{ }^{\circ} \mathrm{C}$ and $\mathrm{P}=10 \mathrm{MPa}$ was 20 days. Three phases formed under these Conditions, differing in crystal shapes and colors. Semi quantitative X-ray spectral analysis (Cam Scan 4DV+ EDA Link AN 1000) of the phase reported here showed the presence of $\mathrm{Mn}$ and $\mathrm{P}$ in the crystals in an atomic ratio of 3: 2. Its amount can be estimated to $45 \%$ of the total yield. The two other phases were semitransparent yellow flat needles of $\left(\mathrm{NH}_{4}\right) \mathrm{Mn}_{2} \mathrm{O}\left(\mathrm{PO}_{4}\right) \quad\left(\mathrm{HPO}_{4}\right)\left(\mathrm{H}_{2} \mathrm{O}\right)$ (45\%) and transparent crystals of turquoise color and irregular shape of $\mathrm{NH}_{4} \mathrm{Ga}_{2} \mathrm{Mn}\left(\mathrm{PO}_{4}\right)_{3}\left(\mathrm{H}_{2} \mathrm{O}\right)(10 \%)$ [12].

\subsection{LiMnPO4}

LiMnPO4 [13] was synthesized in the following steps. $\mathrm{MnCl}_{2}$ (0.375 mol), $\mathrm{H}_{3} \mathrm{PO}_{4}(0.375 \mathrm{~mol})$ and ascorbic acid (12.5 g) were mixed and stirred. An aqueous solution containing $\mathrm{LiOH}(26.5 \mathrm{~g})$ was slowly added into the mixed solution with stirring. The solution was further stirred for 2 hours and was then transferred into a high-pressure reactor placed in an oven at $180^{\circ} \mathrm{Cfor} 18$ hours. The resulting precipitate was collected by centrifugal filtration and washed several times with deionized water before being dried at $60^{\circ} \mathrm{C}$ for 24 hours. LiMn1-xFexPO4 $(x=0.2,0.3,0.4)$ was prepared by the same procedure as $\mathrm{LiMnPO}_{4} \cdot \mathrm{MnCl}_{2}$ and $\mathrm{FeSO}_{4} \cdot 7 \mathrm{H}_{2} \mathrm{O}$ totaled $0.375 \mathrm{~mol}$ with a varied $\mathrm{Fe} / \mathrm{Mn}$ ratio. The LiMn1-xFexPO4 $(\mathrm{x}=0,0.2,0.3,0.4) / \mathrm{C}$ composite material was synthesized by mixing $\mathrm{LiMn} 1-\mathrm{xFexPO} \mathrm{P}_{4}(\mathrm{x}=0,0.2,0.3,0.4)$ with glucose at a mass ratio of 4:1.The mixture was ball-milled for 6 hours, transferred into a tube furnace and sintered at $700^{\circ} \mathrm{C}$ for 5 hours under an Ar atmosphere.

\subsection{KMnPO4}

$\mathrm{KMnPO}_{4} \cdot \mathrm{H}_{2} \mathrm{O}$ [14] was prepared by precipitation from aqueous solution by addition of a solution of $\mathrm{MnSO} 4$ to a large excess of concentrated $\mathrm{K}_{2} \mathrm{HPO}_{4}$. Powder neutron-diffraction data were obtained at $300 \mathrm{~K}$ and $1.7 \mathrm{~K}$ using the powder diffractometer D2B at the Institute Laue Langevin, Grenoble, France: The wavelength used was $1.594 \mathrm{~A}$. The crystal and magnetic structures were refined using the Rietveld method. The magnetization measurements were carried out in a magnetic field up to $6.5 \mathrm{~T}$ using an extraction method.

\subsection{1 $\mathrm{Na}_{0.50} \mathrm{Mn}_{0.25} \mathrm{Ti}_{2}\left(\mathrm{PO}_{4}\right)_{3}$}

The compounds $\mathrm{Na} 0,5 \mathrm{Mn}_{0,25} \mathrm{Ti}_{2}\left(\mathrm{PO}_{4}\right)_{3}(\mathrm{M}=\mathrm{Mn}, \mathrm{Ni})$ are synthesized by a solid reaction method.

\section{$1 / 4 \mathrm{Na}_{2} \mathrm{CO}_{3}+1 / 4 \mathrm{MnCO}_{3}+2 \mathrm{TiO}_{2}+3\left(\mathrm{NH}_{4}\right)_{2} \mathrm{HPO}_{4} \longrightarrow$ $\mathrm{Na}_{0.50} \mathrm{Mn}_{0.25} \mathrm{Ti}_{2}\left(\mathrm{PO}_{4}\right)_{3}+8 \mathrm{NH}_{3}+6 \mathrm{H}_{2} \mathrm{O}$}

In the preparation, the titanium oxide" $\mathrm{TiO}_{2}$ ", carbonates" $\mathrm{M}^{\mathrm{I}} \mathrm{CO}_{3} "$, and ammonium hydrogen phosphate " $\left(\mathrm{NH}_{4}\right)_{2} \mathrm{HPO}_{4}$ " were used as precursors. These reagents are milled for one hour in a porcelain mortar in order to achieve good homogenization and the finest particle size possible.

The mixture is placed in a crucible and undergoes several heat treatments, at increasing temperatures, between each grinding operation, to ensure their homogeneity and promote solid state diffusion. They are finally brought to a temperature of $1050^{\circ} \mathrm{C}$ for 5 hours. The $\mathrm{Na}_{0.5} \mathrm{M}_{0 \cdot 25} \mathrm{Ti}_{2}\left(\mathrm{PO}_{4}\right)_{3}(\mathrm{M}=\mathrm{Mn}, \mathrm{Ni})$ powders are yellow and red [15].

\section{SAMPLE CHARACTERIZATION}

\section{X-ray powder diffraction}

The calculation of the unit-cell parameters and the analysis of the X-ray diffractogram enabled us to verify the purity of the synthesized product. The mesh parameters of these monophosphates are collected in table 1

Table 1: Main crystallographic data for the monophosphates associated with manganese

\begin{tabular}{|c|c|c|c|c|c|c|}
\hline Formula & $\begin{array}{l}\mathbf{a}(\stackrel{\mathbf{A}}{ }) \\
\alpha\left({ }^{\circ}\right)\end{array}$ & $\begin{array}{l}\mathbf{b}(\stackrel{\mathbf{A}}{ }) \\
\beta\left({ }^{\circ}\right)\end{array}$ & $\begin{array}{l}\mathbf{c}(\mathbf{A}) \\
\gamma\left({ }^{\circ}\right)\end{array}$ & S.G. & $\mathbf{Z}$ & References \\
\hline $\mathrm{MnHPO}_{4} \cdot \mathrm{H}_{2} \mathrm{O}$ & 10.44 & 10.87 & 10.22 & $\begin{array}{l}\text { Pbca } \\
\end{array}$ & 8 & [6] \\
\hline $\mathrm{RbMnPO}_{4}$ & 8.94635 & $\begin{array}{l}5.43415 \\
90.2912\end{array}$ & 9.10250 & $\mathrm{P} 2_{1}$ & $\mathrm{Z}$ & [7] \\
\hline $\mathrm{NaMnPO}_{4} \cdot 3 \mathrm{H}_{2} \mathrm{O}$ & 10.5280 & 6.3208 & 4.9851 & $\mathrm{Pmn}_{1}$ & $\mathrm{Z}$ & [9] \\
\hline $\mathrm{Na}_{4} \mathrm{Mn}_{3}\left(\mathrm{PO}_{4}\right)_{2}\left(\mathrm{P}_{2} \mathrm{O}_{7}\right)$ & 17.991 & 6.648 & 10.765 & $\mathrm{Pn} 2_{1} \mathrm{a}$ & $\bar{Z}$ & [10] \\
\hline $\mathrm{Mn}_{3}\left(\mathrm{PO}_{4}\right)_{2}$ & 5.2344 & $\begin{array}{l}6.6739 \\
95.276\end{array}$ & 8.9688 & $\mathrm{P} 2_{1} / \mathrm{n}$ & 2 & [12] \\
\hline $\mathrm{CsMnPO} 4$ & 91.185 & 5.839 & 5.65 & $\mathrm{Pna}_{1}$ & $\mathrm{Z}$ & [11] \\
\hline LiMnPO4 & 10.45139 & 6.10128 & 4.73492 & $\mathrm{Pmn} 2_{1}$ & $\mathrm{Z}$ & [13] \\
\hline KMnPO4 & 5.4813 & 8.6274 & 8.8865 & $\mathrm{P}_{4}$ & $\mathrm{Z}$ & [14] \\
\hline $\mathrm{Na}_{0.50} \mathrm{Mn}_{0 \cdot 25} \mathrm{Ti}_{2}\left(\mathrm{PO}_{4}\right)_{3}$ & 14.60 & 13.31 & 2.67 & Pmmm & 4 & [15] \\
\hline
\end{tabular}

2. Characterization of $\mathrm{PO}_{4}{ }^{3-}$ in $\mathrm{Na}_{0.50} \mathrm{Mn}_{0.25} \mathrm{Ti}_{2}\left(\mathrm{PO}_{4}\right)_{3}$ by

IR vibration spectrometry.

The infrared absorption spectrum allowed us to characterize the compound and to verify the nature of the inserted species. 
Hamza Marouani et al., International Journal of Emerging Trends in Engineering Research, 8(7), July 2020, 4784 - 4798

The characteristic absorptions of the compound are shown in Figure 1 [10].

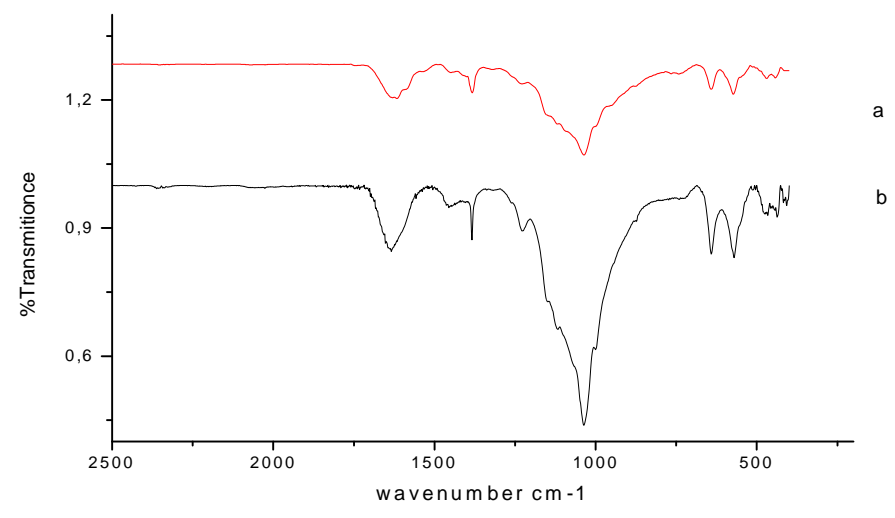

Figure 1: Infrared spectra of: a) $\mathrm{Na}_{0.5} \mathrm{Mn}_{0.25} \mathrm{Ti}_{2}\left(\mathrm{PO}_{4}\right)_{3}$, b) $\mathrm{Na}_{0.5} \mathrm{Ni}_{0.25} \mathrm{Ti}_{2}\left(\mathrm{PO}_{4}\right)_{3}$

The assignment of characteristic bands observed in the compound's spectra (Table) is made based on factor group analysis, and on previous results made on homologous compounds Infrared spectroscopy analysis reveals several bands, in particular those attributable to $\mathrm{PO}_{4}{ }^{3-}$ ions. The results are shown in Table 2.

Table 2: IR data for $\mathrm{Na}_{0.5} \mathrm{M}_{0.25} \mathrm{Ti}_{2}\left(\mathrm{PO}_{4}\right)_{3}(\mathrm{M}=\mathrm{Mn}, \mathrm{Ni})$, band positions and assignments

\begin{tabular}{|c|c|}
\hline & Vibrations \\
\hline Frequencies $v\left(\mathrm{~cm}^{-1}\right)$ & $\delta_{\mathrm{S}} \mathrm{OPO}^{-} \quad\left(v_{2}:\right.$ symmetric deformation $)$ \\
600 & $\delta_{\text {as }} \mathrm{OPO}^{-} \quad\left(v_{4}\right.$ : asymmetric deformation $)$ \\
1316 & $v_{\mathrm{S}} \mathrm{PO} \quad\left(v_{1}:\right.$ symmetric stretching $)$ \\
1410 & $v_{\text {as }} \mathrm{PO} \quad\left(v_{3}:\right.$ asymmetric stretching $)$ \\
\hline
\end{tabular}

This spectrum has four distinct frequency domains:

Domain I: between 1460 and $980 \mathrm{~cm}^{-1}$ due to the anti-symmetric and symmetrical vibration of the $\mathrm{PO}_{4}{ }^{3-}$ ion.

Domain II: between 660 and $500 \mathrm{~cm}^{-1}$ corresponds to the anti-symmetric vibrations of deformation of the $\mathrm{PO}_{4}{ }^{3-}$ ion Domain III: between 450 and $400 \mathrm{~cm}^{-1}$ due to the symmetrical vibration of the $\mathrm{PO}_{4}{ }^{3-}$ ion.

Domain IV: less than $400 \mathrm{~cm}^{-1}$ corresponds to external vibrations.

Based on the frequencies of the internal modes of the $\mathrm{PO}_{4}{ }^{3-}$ ion, in the first frequency domain, we assign the frequency lines $1131,1074,1020$ and $1001 \mathrm{~cm}^{-1}$ to the anti-symmetric vibrations of the ion $\mathrm{PO}_{4}{ }^{3-}$.

The $982 \mathrm{~cm}-1$ frequency line is due to the symmetric valence vibrations relative to the $\mathrm{PO}_{4}{ }^{3-}$ ion. The frequency bands 650 , 621 and $550 \mathrm{~cm}^{-1}$ correspond to the vibrations of anti-symmetric deformation of the $\mathrm{PO}_{4}{ }^{3-}$ ion. Similarly, the frequency lines 439,401 and $349 \mathrm{~cm}^{-1}$ are due to symmetrical deformation vibrations of the two $\mathrm{PO}_{4}{ }^{3-}$ ions. The lines of frequency lower than $401 \mathrm{~cm}^{-1}$ are due to the external vibrations of $\mathrm{PO}_{4}{ }^{3-}$ ions, $\mathrm{TiO}$ groups.

\section{CONDENSED PHOSPHATES}

The complexity of classification appears with condensed phosphates because of the existence of several types of condensation geometries. We said that condensed phosphoric anions were constructed by a variable number of $\mathrm{PO}_{4}$ tetrahedra pooling vertices. A tetrahedron engaged in such a group may share one, two or three of its vertices with the adjacent tetrahedra. We will therefore have to distinguish three very different types of $\mathrm{PO}_{4}$ tetrahedra:

- Those whose only oxygen atom is engaged in a P-O-P bond which will be designated as terminal tetrahedra,

- Those who share two of their oxygen atoms with neighbouring tetrahedra which will be referred to as internal tetrahedra

- Those which share three of them and which are usually known neighbouring the names of ternary tetrahedra or branching tetrahedron.

\subsection{Oligophosphates}

We have seen above that in these salts the anionic groups are expressed by the general Formula $\left[\mathrm{P}_{\mathrm{n}} \mathrm{O}_{3 \mathrm{n}+1}\right]$.

The valence of such a group being equal to $(n+2)$. Such anionic groups are currently known for $\mathrm{n}=2,3,4$ and 5 . Terminology used for this salt family has changed somewhat over time. Formerly known as pyrophosphates $(\mathrm{n}=2)$, tripolyphosphates $(\mathrm{n}=3)$ etc $\ldots$ they now receive the shorter names of diphosphates $(n=2)$, triphosphates $(n=3)$ etc ... We summarize these two terminologies in Table 3.

Table 3: Nomenclature used for oligophosphates

\begin{tabular}{|c|c|c|c|}
\hline $\mathrm{N}$ & Anions & Old nomenclature & Current nomenclature \\
\hline 2 & {$\left[\mathrm{P}_{2} \mathrm{O}_{7}\right]^{4-}$} & Pyrophosphates & Diphosphates \\
\hline 3 & {$\left[\mathrm{P}_{3} \mathrm{O}_{10}\right]^{5-}$} & Tripolyphosphates & Triphosphates \\
\hline 4 & {$\left[\mathrm{P}_{4} \mathrm{O}_{13}\right]^{6-}$} & Tetrapolyphosphate & Tetraphosphates (linear) \\
& & & Isotetraphosphates (amified) \\
\hline 5 & {$\left[\mathrm{P}_{5} \mathrm{O}_{16}\right]^{7-}$} & Pentapolyphosphates & Pentaphosphates \\
\hline
\end{tabular}

\section{1. $\mathbf{P}_{2} \mathbf{O}_{7}{ }^{4-}$}

In this part we present the synthesis of Diphosphates associated with manganese by the various synthetic methods, structural characterization thus studies by IR vibration spectrometry of their anions. We have been able to isolate and 
Hamza Marouani et al., International Journal of Emerging Trends in Engineering Research, 8(7), July 2020, 4784 - 4798

characterize several phosphates of $\mathrm{Mn}-\mathrm{P}_{2} \mathrm{O}_{7}$ type as an example:

$\mathrm{ZnMnP}_{2} \mathrm{O}_{7}, \mathrm{Sr}_{2} \mathrm{Mn}\left[\mathrm{PO}_{4}\right]\left[\mathrm{P}_{2} \mathrm{O}_{7}\right], \mathrm{Na}_{4} \mathrm{Mn}_{3}\left(\mathrm{PO}_{4}\right)_{2}\left(\mathrm{P}_{2} \mathrm{O}_{7}\right)$, $\mathrm{Ni}_{1,184} \mathrm{Mn}_{0,816} \mathrm{P}_{2} \mathrm{O}_{7}, \mathrm{MnNiP}_{2} \mathrm{O}_{7}$ and $\operatorname{LiMn}\left(\mathrm{H}_{2} \mathrm{P}_{2} \mathrm{O}_{7}\right)_{2}$

\subsubsection{Sample preparation}

\section{1. $\mathrm{ZnMnP}_{2} \mathrm{O}_{7}$}

$\mathrm{ZnMnP}_{2} \mathrm{O}_{7}$ diphosphate is prepared in powder by the ceramic method from the reagents $\mathrm{ZnCO}_{3}, \mathrm{MnCO}_{3}$ and $\left(\mathrm{NH}_{4}\right)_{2} \mathrm{HPO}_{4}$, these reagents taken in stoichiometric proportions are finely ground in an agate mortar. Afterwards, the mixture is placed in a silica crucible, kept in air at $120^{\circ} \mathrm{C}$ for 15 hours and gradually brought to $500{ }^{\circ} \mathrm{C}$ in order to avoid a sudden decomposition of carbonates or ammonium hydrogeno-phosphate. Once the decomposition is complete, the mixture is well-grounded and treated at $900{ }^{\circ} \mathrm{C}$ for 24 hours. Finally, the powder is quenched in the air [16].

\section{2. $\mathrm{Sr}_{2} \mathrm{Mn}\left[\mathrm{PO}_{4}\right]\left[\mathbf{P}_{2} \mathbf{O}_{7}\right]$}

(59 mg, $0.4 \mathrm{mmol}$ ), $\mathrm{Mn}_{2} \mathrm{O}_{3}(63 \mathrm{mg}, 0.4 \mathrm{mmol})$ and $0.2 \mathrm{ml}$ of $85 \% \mathrm{H}_{3} \mathrm{PO}_{4}$. A reaction mixture was loaded into quartz tubes and filled with $0.5 \mathrm{ml}$ water. The autoclave was heated at 375 ${ }^{\circ} \mathrm{C}$ for 3 days and then cooled to room temperature. The solid products were recovered by suction filtration and washed with distilled water. Very few red block-like crystals of the title compound were obtained. However, the reproduction of the crystal preparation was not successful [17].

\section{3. $\mathrm{Na}_{4} \mathrm{Mn}_{3}\left(\mathrm{PO}_{4}\right)_{2}\left(\mathrm{P}_{2} \mathrm{O}_{7}\right)$}

$\mathrm{Na}_{4} \mathrm{Mn}_{3}\left(\mathrm{PO}_{4}\right)_{2}\left(\mathrm{P}_{2} \mathrm{O}_{7}\right)$ was synthesized via a conventional solid-state reaction. A stoichiometric quantity of $\mathrm{Na}_{4} \mathrm{P}_{2} \mathrm{O}_{7}(95$ $\%$, Aldrich), $\mathrm{Mn}_{2} \mathrm{C}_{2} \mathrm{O}_{4} \cdot 2 \mathrm{H}_{2} \mathrm{O}$ (99\%, Alfa Aesar) and $\mathrm{NH}_{4} \mathrm{H}_{2} \mathrm{PO}_{4}(98 \%$ ACS reagent, Aldrich) was mixed using wet ball milling at $200 \mathrm{rpm}$ for 12 hours in acetone. Following ball-milling, the acetone was dried out at $70^{\circ} \mathrm{C}$ for 12 hours. The mixture was calcinated at $300^{\circ} \mathrm{C}$ for 6 hours in air, and the resulting powder was pelletized under a pressure of $200 \mathrm{~kg}$ $\mathrm{cm}^{-2}$, and sintered again at $600^{\circ} \mathrm{C}$ for 6 hours in air Carbon coating of the $\mathrm{Na}_{4} \mathrm{Mn}_{3}\left(\mathrm{PO}_{4}\right)_{2}\left(\mathrm{P}_{2} \mathrm{O}_{7}\right)$ sample was carried out to enhance the electrical conductivity using pyromellitic acid (PA) $\left(\mathrm{C}_{10} \mathrm{H}_{6} \mathrm{O}_{2}, 96 \%\right.$, Alfa Aesar). $\mathrm{Na}_{4} \mathrm{Mn}_{3}\left(\mathrm{PO}_{4}\right)_{2}\left(\mathrm{P}_{2} \mathrm{O}_{7}\right)$, and PA were mixed using a planetary ball-milling with a mass ratio of 9:1, and the ground mixture was annealed at $600^{\circ} \mathrm{C}$ for 2 hours under an Ar atmosphere. The carbon content was approximately $3 \mathrm{wt} \%$ of the total powder sample [18].

\section{4. $\mathrm{Ni}_{1,184} \mathrm{Mn}_{0,816} \mathrm{P}_{2} \mathrm{O}_{7}$}

All samples were prepared by direct fusion. Stoichiometric quantities of $\mathrm{NiO}, \mathrm{MnCO}_{3}$ and $\left(\mathrm{NH}_{4}\right)_{2} \mathrm{HPO}_{4}$ were ground together and heated in a platinum crucible to $393 \mathrm{~K}$ for $15 \mathrm{~h}$ and then progressively to $773 \mathrm{~K}$ and then $923 \mathrm{~K}$. After the evolution of $\mathrm{CO}_{2}, \mathrm{NH}_{3}$ and $\mathrm{H}_{2} \mathrm{O}$ from the decomposition of the carbonate and ammonium hydrogen phosphate ceased, the temperature of the mixture (after regrinding) was raised to $1173 \mathrm{~K}$ for $20 \mathrm{~h}$. The material was cooled in air to room temperature [19].

\section{5. $\mathrm{MnNiP}_{2} \mathrm{O}_{7}$}

The binary $\mathrm{Mn}_{0.5} \mathrm{Ni}_{0.5} \mathrm{HPO}_{4} \cdot \mathrm{H}_{2} \mathrm{O}$ compound was prepared by the solution coprecipitation method using $\mathrm{Mn}(\mathrm{c})$ (c, complexometric) (99.99\%, Merck), $\mathrm{NiCO}_{3}(99.99 \%$, Merck), and $\mathrm{H}_{3} \mathrm{PO}_{4}(86.4 \% \mathrm{w} / \mathrm{w}$, Merck) as starting materials. Following the procedure, $1.3894 \mathrm{~g}$ of $\mathrm{Mn}(\mathrm{c})$ and $1.4293 \mathrm{~g}$ of $\mathrm{NiCO}_{3}$ (a mole ratio corresponding to the nominal composition of $\mathrm{Mn}$ : Co ratio of 1.0:1.0) were dissolved in $70 \% \mathrm{H} 3 \mathrm{PO} 4$ (86.4\% w/w $\mathrm{H}_{3} \mathrm{PO}_{4}$ dissolved in deionized (DI) water) with continuous stirring at ambient temperature. The resulting solution was stirred until $\mathrm{CO}_{2}(\mathrm{~g})$ was completely evolved (5-15 $\mathrm{min}$ ) and the precipitate was obtained. Then 10 $\mathrm{mL}$ of acetone was added to the obtained nearly dry sample to allow a highly crystalline products to be developed. The pale green solid of $\mathrm{Mn}_{0.5} \mathrm{Ni}_{0.5} \mathrm{HPO}_{4} \cdot \mathrm{H}_{2} \mathrm{O}$ product was filtered by a suction pump, washed with acetone until free from phosphate ion, and dried in air. Its final decomposition product seemed to occur at temperatures above $673 \mathrm{~K}$ (Figure 1). The dried pale green solid than was calcined in a box furnace at $773 \mathrm{~K}$ for $2 \mathrm{~h}$ in air. The final product was obtained as a pale blue solid [20].

$$
\begin{aligned}
& \mathrm{Mn}_{0.5} \mathrm{Ni}_{0.5} \mathrm{HPO}_{4} \cdot \mathrm{H}_{2} \mathrm{O} \longrightarrow \mathrm{Mn}_{0.5} \mathrm{Ni}_{0.5} \mathrm{HPO}_{4}+\mathrm{H}_{2} \mathrm{O} \\
& \mathrm{Mn}_{0.5} \mathrm{Ni}_{0.5} \mathrm{HPO}_{4} \longrightarrow 1 / 2 \mathrm{MnNiP}_{2} \mathrm{O}_{7}+1 / 2 \mathrm{H}_{2} \mathrm{O}
\end{aligned}
$$

\section{6. $\operatorname{LiMn}\left(\mathrm{H}_{2} \mathbf{P}_{2} \mathbf{O}_{7}\right)_{2}$}

The title compound was synthesized from a mixture of $\mathrm{Mn}_{2} \mathrm{O}_{3}$ $(1.5 \mathrm{~g})$ and concentrated $\mathrm{H}_{3} \mathrm{PO}_{4}(30 \mathrm{~mL}, 85 \%)$ placed in a borosilicate beaker and stirred at $250{ }^{\circ} \mathrm{C}$ until completely dissolved. Afterward, $\mathrm{Li}_{2} \mathrm{CO}_{3}(5 \mathrm{~g})$ was added, corresponding to the molar ratio Li: $\mathrm{Mn}: \mathrm{P}$ of 13.5:1.9:42. The mixture was stirred for $24 \mathrm{~h}$. The resulting purple precipitate was washed with water, filtered, and finally washed with acetone [21].

\section{7. $\mathrm{BaMnP}_{2} \mathrm{O}_{7}$ monoclinic}

A mixture of $\mathrm{BaCO}_{3}(0.987 \mathrm{~g}, 5.00 \mathrm{mmol}), \mathrm{MnO}_{2}(0.435 \mathrm{~g}$, $5.00 \mathrm{mmol})$ and $\mathrm{P}_{2} \mathrm{O}_{5}(0.710 \mathrm{~g}, 5.00 \mathrm{mmol})$ was ground thoroughly in a mortar, and then transferred to a ceramic crucible. The crucible was then placed in the tube furnace and heated in air to $1100^{\circ} \mathrm{C}$ for $72 \mathrm{~h}$. At the end of the heating period, the furnace was cooled slowly (approximately $5^{\circ} \mathrm{C} / \mathrm{min}$ ) to room temperature. At this temperature the sample was removed from the oven. A yellow crystal was cleaved from the bulk sample and analysed by single-crystal diffraction. It was found to belong to the monoclinic crystalline system [22].

\section{8. $\mathrm{BaMnP}_{2} \mathrm{O}_{7}$ triclinic}

A mixture of $\mathrm{BaCO}_{3}(0.987 \mathrm{~g}, 5.00 \mathrm{mmol}), \mathrm{MnO}_{2}(0.436 \mathrm{~g}$, $5.01 \mathrm{mmol})$ and $\mathrm{P}_{2} \mathrm{O}_{5}(0.710 \mathrm{~g}, 5.00 \mathrm{mmol})$ was ground thoroughly in a mortar, and then transferred to a ceramic 
Hamza Marouani et al., International Journal of Emerging Trends in Engineering Research, 8(7), July 2020, 4784 - 4798

crucible. The crucible was then placed in the oven (Thermolyne Model F21125) and heated in air to $1000^{\circ} \mathrm{C}$ for $72 \mathrm{~h}$. After the heating period, the oven was cooled slowly (approximately $5^{\circ} \mathrm{C} / \mathrm{min}$ ) to room temperature.

At this temperature the sample was removed from the oven. A yellow crystal was cleaved from the bulk sample and analysed by single crystal diffraction. It was found to belong to the triclinic crystalline system. An X-ray powder diffraction analysis indicated the bulk sample to be the pure triclinic form [22].

\subsubsection{Sample characterization}

\section{X-ray powder diffraction}

The calculation of the mesh parameters and the analysis of the X-ray diffractogram enabled us to verify the purity of the synthesized product. The mesh parameters of these monophosphates are collected in table 4

Table 4: Main Crystallographic data for the

\begin{tabular}{|c|c|c|c|c|c|c|}
\hline Formula & $\begin{array}{l}\mathbf{a}(\AA \mathbf{(}) \\
\alpha\left(\left(^{\circ}\right)\right.\end{array}$ & $\begin{array}{l}\mathbf{b}(\AA) \\
\beta\left(\left(^{\circ}\right)\right.\end{array}$ & $\begin{array}{l}\mathbf{c}(\stackrel{\AA}{\mathbf{A}}) \\
\gamma\left(\left(^{\circ}\right)\right.\end{array}$ & S.G. & $\mathbf{Z}$ & $\begin{array}{l}\text { Refer } \\
\text { ences }\end{array}$ \\
\hline $\mathrm{ZnMnP}_{2} \mathrm{O}_{7}$ & 6.6141 & $\begin{array}{l}8.4366 \\
103.948\end{array}$ & 4.5305 & $\mathrm{C} 2 / \mathrm{m}$ & 2 & [16] \\
\hline $\begin{array}{c}\mathrm{Sr}_{2} \mathrm{Mn} \\
{\left[\mathrm{PO}_{4}\right]\left[\mathrm{P}_{2} \mathrm{O}_{7}\right]}\end{array}$ & 6.641 & $\begin{array}{l}6.8341 \\
99.22\end{array}$ & 9.554 & $\begin{array}{c}\mathrm{P} 12_{1} / \mathrm{c} \\
1\end{array}$ & 4 & [17] \\
\hline $\begin{array}{c}\mathrm{Na}_{4} \mathrm{Mn}_{3}\left(\mathrm{PO}_{4}\right)_{2}\left(\mathrm{P}_{2} \mathrm{O}_{7}\right. \\
)\end{array}$ & 17.991 & 6.648 & 10.765 & $\mathrm{Pna}_{1}$ & 4 & [18] \\
\hline $\mathrm{Ni}_{1,184} \mathrm{Mn}_{0,816} \mathrm{P}_{2} \mathrm{O}_{7}$ & 6.557 & $\begin{array}{c}8.738 \\
103.240\end{array}$ & 4,498 & $\mathrm{Cm}$ & 2 & [19] \\
\hline $\mathrm{MnNiP}_{2} \mathrm{O}_{7}$ & 6.546 & $\begin{array}{c}8.438 \\
102.88\end{array}$ & 4.616 & $\mathrm{C} 2 / \mathrm{m}$ & 4 & [20] \\
\hline $\operatorname{LiMn}\left(\mathrm{H}_{2} \mathrm{P}_{2} \mathrm{O}_{7}\right)_{2}$ & 11.1359 & $\begin{array}{l}12.8206 \\
105.73\end{array}$ & 8.6934 & $\mathrm{C} 12 / \mathrm{C} 1$ & 4 & [21] \\
\hline $\mathrm{BaMnP}_{2} \mathrm{O}_{7}$ & 12.825 & $\begin{array}{l}8.633 \\
90.08\end{array}$ & 5.5537 & $\mathrm{P} 2 / \mathrm{n}$ & 2 & [22] \\
\hline $\mathrm{BaMnP}_{2} \mathrm{O}_{7}$ & $\begin{array}{c}5.473 \\
102.10\end{array}$ & $\begin{array}{r}7.59 \\
86.03\end{array}$ & $\begin{array}{r}7.166 \\
89.29\end{array}$ & P-1 & 2 & [22] \\
\hline
\end{tabular}

diphosphates associated to manganese

\section{Characterization of $\mathrm{P}_{2} \mathrm{O}_{7}{ }^{4-}$ in $\mathrm{BaMnP}_{2} \mathrm{O}_{7}$ by IR}

vibration spectrometry.

IR absorption spectra of various compounds are recorded in the interval $1500-350 \mathrm{~cm}^{-1}$, absorption field of the ions contained in condensed phosphates. As for the Raman scattering spectra, they are derived from 25 to $1500 \mathrm{~cm}^{-1}$, including the field of external modes of cations and anions. Table 5 contains the main stretching and bending vibrations of $\mathrm{P}_{2} \mathrm{O}_{7}^{4-}$ anions [23].
Table 5: IR Frequency characteristics (in $\mathrm{cm}^{-1}$ ) for $\mathrm{P}_{2} \mathrm{O}_{7}^{4-}$ anions

\begin{tabular}{|c|c|}
\hline Frequencies $v\left(\mathrm{~cm}^{-1}\right)$ & Vibrations \\
\hline $1115-1250 \mathrm{~cm}^{-1}$ & $v_{\text {as }}\left(\mathrm{PO}_{3}\right)$ \\
\hline $1110-990 \mathrm{~cm}^{-1}$ & $v_{\mathrm{s}}\left(\mathrm{PO}_{3}\right)$ \\
\hline $960-720 \mathrm{~cm}^{-1}$ & $v_{\text {as }}(\mathrm{POP})$ \\
\hline $660-529 \mathrm{~cm}^{-1}$ & $\delta_{\text {as }}\left(\mathrm{PO}_{3}\right)$ \\
\hline $529-300 \mathrm{~cm}^{-1}$ & $\delta_{\mathrm{s}}\left(\mathrm{PO}_{3}\right)$ \\
\hline
\end{tabular}

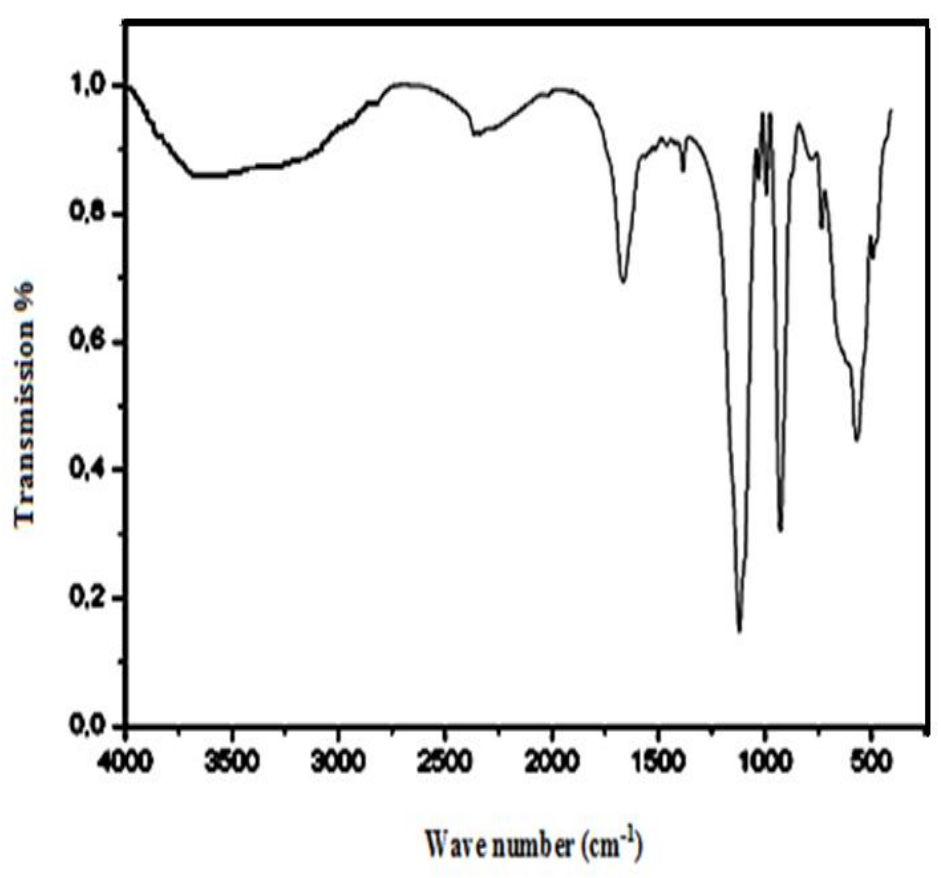

Figure 2: IR spectrum of the phosphate $\mathrm{BaMnP}_{2} \mathrm{O}_{7}$

In this part we present the synthesis of Diphosphates associated with manganese by the various synthetic methods, structural characterization thus studies by IR vibration spectrometry of their anions. We have been able to isolate and characterize several phosphates of $\mathrm{Mn}-\mathrm{P}_{2} \mathrm{O}_{7}$ type as an example.

\section{$\mathrm{Mn}_{0.5} \mathrm{NH}_{4} \mathrm{H}_{2} \mathbf{P}_{2} \mathbf{O}_{7} \cdot \mathrm{H}_{2} \mathrm{O}$}

Solutions of $\mathrm{Na}_{4} \mathrm{P}_{2} \mathrm{O}_{7} .10 \mathrm{H}_{2} \mathrm{O}(0.1 \mathrm{M}), \mathrm{NH}_{4} \mathrm{C} 1(0.1 \mathrm{M})$ and $\mathrm{MnCl}_{2} \cdot 4 \mathrm{H}_{2} \mathrm{O}(0.1 \mathrm{M})$ were mixed with a few $\mathrm{mL}$ of concentrated $\mathrm{HCl}$. The resulting solution was left at $30^{\circ} \mathrm{C}$ in bath of sand, and after 4 days pink crystals of $\mathrm{Mn}_{0.5} \mathrm{NH}_{4} \mathrm{H}_{2} \mathrm{P}_{2} \mathrm{O}_{7} \cdot \mathrm{H}_{2} \mathrm{O}$ appeared. $\mathrm{Mn}_{0.5} \mathrm{NH}_{4} \mathrm{H}_{2} \mathrm{P}_{2} \mathrm{O}_{7} \cdot \mathrm{H}_{2} \mathrm{O}$ [24] diphosphate crystallizes in the triclinic system, space group P-1 (C $\mathrm{C}$ i), with two molecules per cell with the following 
unit-cell dimensions :(a)=7.0029(2) $\mathrm{A}, \mathrm{b}=7.4401(2) \AA, c=$ $7.8771(2) \AA, \alpha=80.444(1)^{\circ}, \beta=71.359(1)^{\circ}, \gamma=87.408(1)^{\circ}$, $\mathrm{V}=383.48(2) \AA^{3}$.

\section{2. $\mathbf{P}_{3} \mathrm{O}_{10}{ }^{4-}$}

In this part we present the synthesis of Triphosphates associated with manganese by the various synthetic methods, structural characterization thus studies by IR vibration spectrometry of their anions. We have been able to isolate and characterize several phosphates of $\mathrm{Mn}-\mathrm{P}_{3} \mathrm{O}_{10}$ type as an example.

\subsubsection{Sample preparation}

\section{1. $\mathrm{NaMn}_{6}\left(\mathrm{P}_{2} \mathrm{O}_{7}\right)_{2}\left(\mathrm{P}_{3} \mathrm{O}_{10}\right)$}

The starting materials $\mathrm{Na}_{2} \mathrm{CO}_{3}$ [for (I)] or $\mathrm{KNO}_{3}$ [for (II)], $\mathrm{MnCO}_{3}$ (or $\mathrm{CdCO}_{3}$ ) and $\left(\mathrm{NH}_{4}\right)_{2} \mathrm{HPO}_{4}$ were mixed in a stoichiometry expected to lead to the preparation of $\mathrm{A}_{2} \mathrm{~B}_{3}\left(\mathrm{P}_{2} \mathrm{O}_{7}\right)_{2}$, with $\mathrm{A}=\mathrm{Na}$ and $\mathrm{B}=\mathrm{Mn}$ for (I), and $\mathrm{A}=\mathrm{K}$ and $\mathrm{B}$ $=\mathrm{Cd}$ for (II), according to the following two reactions:

$\mathrm{Na}_{2} \mathrm{CO}_{3}+3 \mathrm{MnCO}_{3}+4\left(\mathrm{NH}_{4}\right)_{2} \mathrm{HPO}_{4} \longrightarrow \mathrm{Na}_{2} \mathrm{Mn}_{3}\left(\mathrm{P}_{2} \mathrm{O}_{7}\right)_{2}$ $+4 \mathrm{CO}_{2}+8 \mathrm{NH}_{3}+6 \mathrm{H}_{2} \mathrm{O}$

The starting mixture was heated slowly to $873 \mathrm{~K}$ to eliminate $\mathrm{NH}_{3}, \mathrm{CO}_{2}$ [and $\mathrm{NO}_{2}$ in (II)] and $\mathrm{H}_{2} \mathrm{O}$, followed by heating to $1223 \mathrm{~K}$ [for(I)] or $1023 \mathrm{~K}$ [for (II)] and slow cooling (6 Khÿ1) to $673 \mathrm{~K}$, whereupon the furnace was allowed to cool to ambient temperature without control. Colorless crystalline solids were obtained [25].

\section{2. $\mathrm{MnNa}_{3} \mathrm{P}_{3} \mathrm{O}_{10} \cdot 12 \mathrm{H}_{2} \mathrm{O}$}

Polycrystalline samples of the $\mathrm{MnNa}_{3} \mathrm{P}_{3} \mathrm{O}_{10} \cdot 12 \mathrm{H}_{2} \mathrm{O}$, were prepared by adding slowly dilute triphosphoric acid to an aqueous solution of nickel II carbonate and sodium carbonate, according to the following chemical reaction:

$\mathrm{H}_{5} \mathrm{P}_{3} \mathrm{O}_{10}+\mathrm{MnCO}_{3}+3 / 2 \mathrm{Na}_{2} \mathrm{CO}_{3}+19 / 2 \mathrm{H}_{2} \mathrm{O} \rightarrow$ $\mathrm{MnNa}_{3} \mathrm{P}_{3} \mathrm{O}_{10} \cdot 12 \mathrm{H}_{2} \mathrm{O}+5 / 2 \mathrm{CO}_{2}$

The preliminary obtained solution was then slowly evaporated at room temperature until Polycrystalline samples of $\mathrm{NiNa}_{3} \mathrm{P}_{3} \mathrm{O}_{10} \cdot 12 \mathrm{H}_{2} \mathrm{O}$ were obtained. The triphosphoric acid used in this reaction was prepared from an aqueous solution of $\mathrm{Na}_{5} \mathrm{P}_{3} \mathrm{O}_{10}$ passed through an ion-exchange resin "Amberlite IR 120". The solution passage rate through the cation exchanger was $2 \mathrm{~mL} / \mathrm{min} \quad$ [26].

\subsubsection{Sample characterization}

\section{X-ray powder diffraction}

The calculation of the mesh parameters and the analysis of the $\mathrm{X}$-ray diffractogram enabled us to verify the purity of the synthesized product. The mesh parameters of these Triphosphates are collected in table 6.
Table 6: Main Crystallographic Data for the Triphosphates associated to manganese.

\begin{tabular}{|c|c|c|c|c|c|c|}
\hline Formula & $\begin{array}{c}\mathbf{a}(\AA) \\
\boldsymbol{\alpha}\left({ }^{\circ}\right)\end{array}$ & $\begin{array}{c}\mathbf{b}(\AA) \\
\boldsymbol{\beta}\left({ }^{\circ}\right)\end{array}$ & $\begin{array}{c}\mathbf{c}(\AA) \\
\left.\boldsymbol{(}^{\circ}\right)\end{array}$ & $\mathbf{S . G .}$ & $\mathbf{Z}$ & References \\
\hline $\mathrm{NaMn}_{6}\left(\mathrm{P}_{2} \mathrm{O}_{7}\right)_{2}\left(\mathrm{P}_{3} \mathrm{O}_{10}\right)$ & 5.3452 & 6.620 & 6.559 & $\mathrm{P} 2_{1} / \mathrm{m}$ & 2 & {$[25]$} \\
& & 107.28 & & & & \\
\hline $\mathrm{MnNa}_{3} \mathrm{P}_{3} \mathrm{O}_{10} \cdot 12 \mathrm{H}_{2} \mathrm{O}$ & 14.71 & 9.33 & 15.13 & $\mathrm{P}_{1} / \mathrm{n}$ & 4 & {$[\mathbf{2 6}]$} \\
& & 89.8 & & & & \\
\hline
\end{tabular}

\section{S.G. Space Group}

\section{Characterization of $\mathrm{P}_{3} \mathrm{O}_{10}$ in $\mathrm{MnNa}_{3} \mathrm{P}_{3} \mathrm{O}_{10} \cdot \mathbf{1 2 H}_{2} \mathrm{O}$ by IR vibration spectrometry.}

The infrared (IR) spectrum (Fig. 3) for kanonerovite was obtained by a Perkin Elmer Fourier spectrometer on a $\mathrm{KBr}$ pellet containing about $0.001 \mathrm{mg}$ of kanonerovite. The positions $\left(\mathrm{cm}^{-1}\right)$ of the main absorption bands are as follows: $447,519,558,668,875,908,992,1034,1117,1153$, $1327,1590,1650,3311,3394$, and 3586

The band corresponding to the $\mathrm{P}-\mathrm{O}$ asymmetrical stretching vibrations has its maximum at $1117 \mathrm{~cm}^{-1}$ and indicates condensation of P-tetrahedra (Mel'nikova et al. 1985); for orthophosphates this maximum is usually localised in the $1020-1080 \mathrm{~cm}^{-1}$ range. The large splitting of the band corresponding to the bending O-P-O-vibrations (558- 668 $\mathrm{cm}^{-1}$ ) is also characteristic for condensed (but not orthophosphates. Furthermore, the $908 \mathrm{~cm}-1$ band of symmetric stretching vibrations of PO4-tetrahedra is characteristic for the condensed phosphates, while in orthophosphates this band is shifted towards higher frequencies $\left(940-960 \mathrm{~cm}^{-1}\right)$ [26].

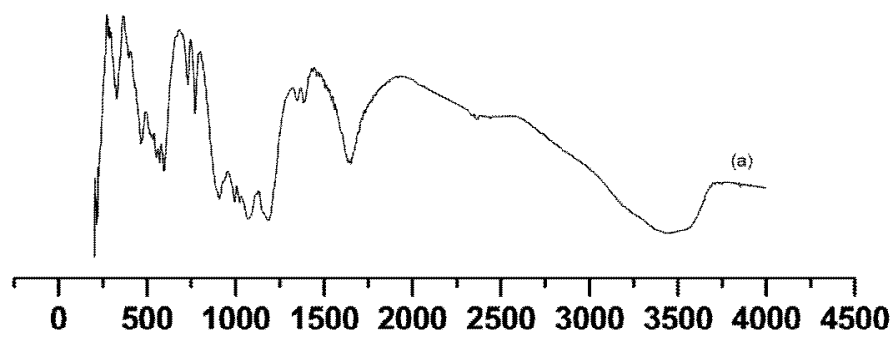

Figure 3: IR spectrum of the phosphate $\mathrm{MnNa}_{3} \mathrm{P}_{3} \mathrm{O}_{10} \cdot 12 \mathrm{H}_{2} \mathrm{O}$

Table 7: Characterization of $\mathrm{MnNa}_{3} \mathrm{P}_{3} \mathrm{O}_{10} \cdot 12 \mathrm{H}_{2} \mathrm{O}$ by IR vibration spectrometry

\begin{tabular}{|c|c|}
\hline Frequencies $v\left(\mathbf{c m}^{-1}\right)$ & Vibrations \\
\hline 3470 & $v \mathrm{O}-\mathrm{H}$ \\
\hline 1653 & $v_{\delta} \mathrm{HOH}$ \\
\hline 1360 & $v \mathrm{P}=\mathrm{O}$ \\
\hline 1253 & $v_{\text {as }} \mathrm{PO}_{2}$ \\
\hline
\end{tabular}


Hamza Marouani et al., International Journal of Emerging Trends in Engineering Research, 8(7), July 2020, 4784 - 4798

\begin{tabular}{|c|c|}
\hline 1214 & $v_{a s} \mathrm{PO}_{2}$ \\
\hline 1188 & $v_{\mathrm{as}} \mathrm{PO}_{3}$ \\
\hline 1102 & $v_{\mathrm{s}} \mathrm{PO}_{2}$ \\
\hline 973 & $v_{\mathrm{s}} \mathrm{PO}_{3}$ \\
\hline 925 & $v_{\mathrm{as}} \mathrm{POP}$ \\
\hline 813 & $v_{\mathrm{as}} \mathrm{POP}$ \\
\hline 773 & $v_{\mathrm{s}} \mathrm{POP}$ \\
\hline 756 & $v_{\mathrm{s}} \mathrm{POP}$ \\
\hline 683 & $\mathrm{v}_{\mathrm{s}} \mathrm{POP}$ \\
\hline 605 & $\delta \mathrm{PO}_{2}$ \\
\hline 562 & $\delta \mathrm{PO}_{3}$ \\
\hline
\end{tabular}

example: $\mathrm{MnNH}_{4} \mathrm{P}_{3} \mathrm{O}_{9}, \mathrm{MnBa}_{2}\left(\mathrm{P}_{3} \mathrm{O}_{9}\right)_{2} \cdot 6 \mathrm{H}_{2} \mathrm{OMnCa}_{2}\left(\mathrm{P}_{3} \mathrm{O}_{9}\right)_{2} \cdot 1$ $0 \mathrm{H}_{2} \mathrm{O}, \mathrm{MnSr}_{2}\left(\mathrm{P}_{3} \mathrm{O}_{9}\right)_{2} \cdot 4 \mathrm{H}_{2} \mathrm{O}, \mathrm{Mn}\left(\mathrm{NH}_{4}\right)_{4}\left(\mathrm{P}_{3} \mathrm{O}_{9}\right)_{2} \cdot 6 \mathrm{H}_{2} \mathrm{O}, \mathrm{MnK}_{4}(\mathrm{P}$ $\left.{ }_{3} \mathrm{O}_{9}\right)_{2}, \mathrm{Mn}_{3}\left(\mathrm{P}_{3} \mathrm{O}_{9}\right)_{2} \cdot 10 \mathrm{H}_{2} \mathrm{O}$

\subsubsection{Sample preparation}

\section{1. $\mathrm{MnNH}_{4} \mathrm{P}_{3} \mathrm{O}_{9}$}

Ammonium polyphosphate $\left(\left(\mathrm{NH}_{4} \mathrm{PO}_{3}\right) \mathrm{n}, \mathrm{n} \sim 700\right.$, Exolit 422 from Hoechst) and manganese dioxide (MnO2, Russian standard GOST 4470-79, Khimreaktiv) were used. Weight ratios of 3:1 and 6:1 for $\mathrm{APP} / \mathrm{MnO}_{2}$ respectively were chosen for detailed study, as the flame retardant additive APP + $\mathrm{MnO}_{2}$ showed maximum efficiency in combustion tests in air and in synthetic oxygen/nitrogen atmospheres (oxygen index test), at these ratios.

Chemical interaction in the $\mathrm{APP} / \mathrm{MnO}_{2}$ systems at high temperature was studied by thermogravimetry (TG) using a Mettler TA 3000 thermal analyzer. Experiments were carded out at a heating rate of $10 \mathrm{~K} \mathrm{~min}^{-1}$ in an argon flow of $100 \mathrm{~cm}$ $3 \mathrm{~min}^{-1}$. Ceramic holders with which APP and $\mathrm{MnO}_{2}$ do not react were used [27].

\section{2. $\mathrm{MnBa}_{2}\left(\mathrm{P}_{3} \mathrm{O}_{9}\right)_{2} \cdot 6 \mathrm{H}_{2} \mathrm{O}$}

Single crystals of $\mathrm{MnBa}_{2}\left(\mathrm{P}_{3} \mathrm{O}_{9}\right)_{2} \cdot 6 \mathrm{H}_{2} \mathrm{O}$ have been prepared by adding slowly dilute cyclotriphosphoric acid to an aqueous solution of barium carbonate and manganese carbonate with a stoichiometric ratio $\mathrm{Ba} / \mathrm{Mn}=2$, according to the following chemical reaction:

$2 \mathrm{H}_{3} \mathrm{P}_{3} \mathrm{O}_{9}+2 \mathrm{BaCO}_{3}+\mathrm{MnCO}_{3} \rightarrow \mathrm{MnBa}_{2}\left(\mathrm{P}_{3} \mathrm{O}_{9}\right)_{2} \cdot 6 \mathrm{H}_{2} \mathrm{O}+3 \mathrm{CO}_{2}$

The so-obtained solution is then slowly evaporated at room temperature until large rectangular prisms of $\mathrm{MnBa}_{2}$ $\left(\mathrm{P}_{3} \mathrm{O}_{9}\right)_{2} \cdot 6 \mathrm{H}_{2} \mathrm{O}$ are obtained. The crystals are stable in air for many months under normal conditions of temperature and hygrometry [28].

\section{3. $\mathrm{MnCa}_{2}\left(\mathrm{P}_{3} \mathrm{O}_{9}\right)_{2} \cdot \mathbf{1 0 H}_{2} \mathrm{O}$ and $\mathrm{MnCa}_{2}\left(\mathrm{P}_{3} \mathrm{O}_{9}\right)_{2}$}

$\mathrm{MnCa}_{2}\left(\mathrm{P}_{3} \mathrm{O}_{9}\right)_{2}$ was obtained by Tridane [3] by total dehydration of $\mathrm{MnCa}_{2}\left(\mathrm{P}_{3} \mathrm{O}_{9}\right)_{2} \cdot 10 \mathrm{H}_{2} \mathrm{O}$ under atmospheric pressure between 400 and $450^{\circ} \mathrm{C} . \mathrm{MnCa}_{2}\left(\mathrm{P}_{3} \mathrm{O}_{9}\right)_{2}$ [3] was prepared, otherwise, using the method of Thiloand Grunze [10]. Stoichiometric quantities of $\left(\mathrm{NH}_{4}\right)_{2} \mathrm{HPO}_{4}, \mathrm{MnCO}_{3}$ and $\mathrm{CaCO}_{3}$ are well ground and mixed, and very progressively heated to $150-200^{\circ} \mathrm{C}$ to expel ammonia and water vapor. The heating is then resumed up to $450^{\circ} \mathrm{C}$, and this temperature is maintained with intervening grindings until a pure phase is obtained, as checked by X-ray diffraction. $\mathrm{MnCa}_{2}\left(\mathrm{P}_{3} \mathrm{O}_{9}\right)_{2}$ was obtained as polycrystalline samples [29]. 
Hamza Marouani et al., International Journal of Emerging Trends in Engineering Research, 8(7), July 2020, 4784 - 4798

\section{4. $\mathrm{MnSr}_{2}\left(\mathrm{P}_{3} \mathrm{O}_{9}\right)_{2} . \mathbf{. 4}_{2} \mathrm{O}$}

The fourth example of cyclotriphosphates, described in this study, with a general formula $\mathrm{M}^{\mathrm{II}} \mathrm{M}^{\mathrm{II}}{ }_{2}\left(\mathrm{P}_{3} \mathrm{O}_{9}\right)_{2} \cdot \mathrm{nH}_{2} \mathrm{O}$ is $\mathrm{MnSr}_{2}\left(\mathrm{P}_{3} \mathrm{O}_{9}\right)_{2} \cdot 4 \mathrm{H}_{2} \mathrm{O}$. This cyclotriphosphate has no isotypic compound. An automatic indexation using the Treor program and Dicvol 91 program showed that $\mathrm{MnSr}_{2}\left(\mathrm{P}_{3} \mathrm{O}_{9}\right)_{2} \cdot 4 \mathrm{H}_{2} \mathrm{O}$ crystallizes in the triclinic system with $\mathrm{M}(20)=29.6$ and $\mathrm{F}(30)=34.4$. The weight loss performed by slowly heating up to a temperature of $400^{\circ} \mathrm{C}$, confirms the compound as a tetrahydrate. Infrared, Raman and non-linear optical studies show that this salt is centrosymmetric. So, the space group of $\mathrm{MnSr}_{2}\left(\mathrm{P}_{3} \mathrm{O}_{9}\right)_{2} \cdot 4 \mathrm{H}_{2} \mathrm{O}$ is $\mathrm{P}-1$ and its main crystallographic features are reported in Table1. Single crystals of $\mathrm{MnSr}_{2}\left(\mathrm{P}_{3} \mathrm{O}_{9}\right)_{2} \cdot 4 \mathrm{H}_{2} \mathrm{O}$ cannot be obtained. Only polycrystalline samples can be prepared by the method of ion-exchange resin “Amberlite IR 120” [30].

\section{5. $\mathrm{Mn}\left(\mathrm{NH}_{4}\right)_{4}\left(\mathrm{P}_{3} \mathrm{O}_{9}\right)_{2} \cdot 6 \mathrm{H}_{2} \mathrm{O}$}

$\mathrm{Mn}\left(\mathrm{NH}_{4}\right)_{4}\left(\mathrm{P}_{3} \mathrm{O}_{9}\right)_{2} \cdot 6 \mathrm{H}_{2}$ is isotypic of four cyclotriphosphates: $\mathrm{ZnK}_{4}\left(\mathrm{P}_{3} \mathrm{O}_{9}\right)_{2} \cdot 6 \mathrm{H}_{2} \mathrm{O}[14], \mathrm{CoRb}_{4}\left(\mathrm{P}_{3} \mathrm{O}_{9}\right)_{2} \cdot 6 \mathrm{H}_{2} \mathrm{ONiRb}_{4}\left(\mathrm{P}_{3} \mathrm{O}_{9}\right)_{2} \cdot 6$ $\mathrm{H}_{2} \mathrm{O}$ and $\mathrm{ZnRb}_{4}\left(\mathrm{P}_{3} \mathrm{O}_{9}\right)_{2} \cdot 6 \mathrm{H}_{2} \mathrm{O}$. This compound was prepared using silver cyclotriphosphate monohydrate as starting material. An aqueous solution of $\mathrm{MnCl}_{2} \cdot 4 \mathrm{H}_{2} \mathrm{O}$ and $\mathrm{NH}_{4} \mathrm{Cl}$ in stoichiometric proportions is added with the corresponding amount of $\mathrm{Ag}_{3} \mathrm{P}_{3} \mathrm{O}_{9} \cdot \mathrm{H}_{2} \mathrm{O}$, according to the following chemical reaction:

$\mathrm{MnCl}_{2} \cdot 4 \mathrm{H}_{2} \mathrm{O}+4 \mathrm{NH}_{4} \mathrm{Cl}+2 \mathrm{Ag}_{3} \mathrm{P}_{3} \mathrm{O}_{9} \cdot \mathrm{H}_{2} \mathrm{O} \rightarrow$

$\mathrm{Mn}\left(\mathrm{NH}_{4}\right)_{4}\left(\mathrm{P}_{3} \mathrm{O}_{9}\right)_{2} \cdot 6 \mathrm{H}_{2} \mathrm{O}+6 \mathrm{AgCl}$

After filtration, to eliminate the insoluble silver chloride, the resulting solution is kept at room temperature until the formation of $\mathrm{Mn}\left(\mathrm{NH}_{4}\right)_{4}\left(\mathrm{P}_{3} \mathrm{O}_{9}\right)_{2} \cdot 6 \mathrm{H}_{2} \mathrm{O}$ as polycrystalline samples [31].

\section{6. $\mathrm{MnK}_{4}\left(\mathrm{P}_{3} \mathrm{O}_{9}\right)_{2}$}

$\mathrm{CdK}_{4}\left(\mathrm{P}_{3} \mathrm{O}_{9}\right)_{2}, \mathrm{MnK} 4\left(\mathrm{P}_{3} \mathrm{O}_{9}\right)_{2}$ and $\mathrm{NiRb}_{4}\left(\mathrm{P}_{3} \mathrm{O}_{9}\right)_{2}$ are isotypic of a series of five cyclotriphosphates corresponding to the general formula $\mathrm{M}^{\mathrm{II}} \mathrm{Tl}_{4}\left(\mathrm{P}_{3} \mathrm{O}_{9}\right)_{2}$ $\left(\mathrm{M}^{\mathrm{II}}=\mathrm{Mg}^{2+}, \mathrm{Co}^{2+}, \mathrm{Zn}^{2+}, \mathrm{Cd}^{2+}, \mathrm{Ca}^{2+}\right)$, of $\mathrm{MnTl}_{4}\left(\mathrm{P}_{3} \mathrm{O}_{9}\right)_{2}$ and also of $\mathrm{MnCa}_{2}\left(\mathrm{P}_{3} \mathrm{O}_{9}\right)_{2}$ described in the present study. The five cyclotriphosphates described above were discovered during the elaboration of various $\mathrm{TlPO}_{3}-\mathrm{M}^{\mathrm{II}}\left(\mathrm{PO}_{3}\right)_{2}$ phase-equilibrium diagrams where they always appear as noncongruent melting compounds. Rakotomahanina-Rolaisoa proposed a model for this atomic arrangement using the magnesium thallium cyclotriphosphate, $\mathrm{MgTl}_{4}\left(\mathrm{P}_{3} \mathrm{O}_{9}\right)_{2}$. $\mathrm{CdK}_{4}\left(\mathrm{P}_{3} \mathrm{O}_{9}\right)_{2}$ was obtained by total dehydration of $\mathrm{CdK}_{4}\left(\mathrm{P}_{3} \mathrm{O}_{9}\right)_{2} \cdot 2 \mathrm{H}_{2} \mathrm{O}$ under atmospheric pressure between 200 and $550^{\circ} \mathrm{C}$. $\mathrm{MnK}_{4}\left(\mathrm{P}_{3} \mathrm{O}_{9}\right)_{2}$ was obtained by total dehydration of $\mathrm{MnK}_{4}\left(\mathrm{P}_{3} \mathrm{O}_{9}\right)_{2} \cdot 2 \mathrm{H}_{2} \mathrm{O}$ under atmospheric pressure between 200 and $550^{\circ} \mathrm{C}$. It is worth noticing that $\mathrm{MnK}_{4}\left(\mathrm{P}_{3} \mathrm{O}_{9}\right)_{2} \cdot 2 \mathrm{H}_{2} \mathrm{O}$ is the isotypic of the corresponding cadmium salt, $\mathrm{CdK}_{4}\left(\mathrm{P}_{3} \mathrm{O}_{9}\right)_{2} \cdot 2 \mathrm{H}_{2} \mathrm{O}$, whose chemical preparation and crystal structure have been reported by M.T. Averbuch-Pouchot. $\mathrm{NiRb}_{4}\left(\mathrm{P}_{3} \mathrm{O}_{9}\right)_{2}$ was obtained by total dehydration of $\mathrm{NiRb}_{4}\left(\mathrm{P}_{3} \mathrm{O}_{9}\right)_{2} \cdot 2 \mathrm{H}_{2} \mathrm{O}$ under atmospheric pressure between 300 and $400^{\circ} \mathrm{C}$. Additional materials as indexing X-ray diffraction patterns of the eight condensed phosphates studied in the present work can be obtained on request to the Moroccan author [31].

\section{7. $\mathrm{MnNa}_{4}\left(\mathrm{P}_{3} \mathrm{O}_{9}\right)_{2} \cdot \mathbf{4} \mathrm{H}_{2} \mathrm{O}-\mathrm{MnNa}_{4}\left(\mathrm{P}_{3} \mathrm{O}_{9}\right)_{2}$}

Crystals of the title compound were prepared by adding slowly dilute cyclotriphosphoric acid to an aqueous solution of manganese carbonate and sodium carbonate with a stoichiometric ratio $\mathrm{Na} / \mathrm{Mn} \mathrm{D} \mathrm{4}$, according to the following chemical reaction:

$$
\begin{aligned}
& 2 \mathrm{H}_{3} \mathrm{P}_{3} \mathrm{O}_{9}+\mathrm{MnCO}_{3}+2 \mathrm{Na}_{2} \mathrm{CO}_{3} 1 \mathrm{H}_{2} \mathrm{O} \quad \mathrm{MnNa}_{4}\left(\mathrm{P}_{3} \mathrm{O}_{9}\right)_{2 .} .4 \mathrm{H}_{2} \mathrm{O} \\
& +3 \mathrm{CO}_{2}
\end{aligned}
$$

The so-obtained solution was then slowly evaporated at room temperature until polycrystalline samples of $\mathrm{MnNa}_{4}\left(\mathrm{P}_{3} \mathrm{O}_{9}\right)_{2} \cdot 4 \mathrm{H}_{2} \mathrm{O}$ were obtained. The cyclotriphosphoric acid used in this reaction was prepared from an aqueous solution of $\mathrm{Na}_{3} \mathrm{P}_{3} \mathrm{O}_{9}$ passed through an ion-exchange resin "Amberlite IR 120"16 $\mathrm{Na}_{3} \mathrm{P}_{3} \mathrm{O}_{9}$ was obtained by thermal treatment of sodium dihydrogenomonophosphate, at $530{ }^{\circ} \mathrm{C}$ for $5 \mathrm{~h}$ in air according to:

$$
3 \mathrm{NaH}_{2} \mathrm{PO}_{4} \longrightarrow \mathrm{Na}_{3} \mathrm{P}_{3} \mathrm{O}_{9}+3 \mathrm{H}_{2} \mathrm{O}
$$

The weight loss performed by slowly heating up to a temperature of $300^{\circ} \mathrm{C}$, confirms the compound as a tetrahydrate, $\mathrm{MnNa}_{4}\left(\mathrm{P}_{3} \mathrm{O}_{9}\right)_{2} \cdot 4 \mathrm{H}_{2} \mathrm{O} . \quad \mathrm{MnNa}_{4}\left(\mathrm{P}_{3} \mathrm{O}_{9}\right)_{2}$ was obtained as polycrystalline samples by total dehydration of $\mathrm{MnNa}_{4}\left(\mathrm{P}_{3} \mathrm{O}_{9}\right)_{2} \cdot 4 \mathrm{H}_{2} \mathrm{O}$ under atmospheric pressure between 300 and $600^{\circ} \mathrm{C}$ [32].

\section{8. $\mathrm{MnAg}_{4}\left(\mathrm{P}_{3} \mathrm{O}_{9}\right)_{2} .6 \mathrm{H}_{2} \mathrm{O}$}

Polycrystalline samples of $\mathrm{MnAg}_{4}\left(\mathrm{P}_{3} \mathrm{O}_{9}\right)_{2} \cdot 6 \mathrm{H}_{2} \mathrm{O}$ were prepared by the metathesis reaction of Boulle (Boulle 1938) using silver cyclotriphosphate monohydrate as starting material. An aqueous solution of $\mathrm{MnCl}_{2} \cdot 4 \mathrm{H}_{2} \mathrm{O}$ is added with the corresponding amount of $\mathrm{Ag}_{3} \mathrm{P}_{3} \mathrm{O}_{9} \cdot \mathrm{H} 2 \mathrm{O}$ in stoichiometric proportions. The reaction scheme is the following:

$\mathrm{MnCl}_{2} \cdot 4 \mathrm{H}_{2} \mathrm{O}+2 \mathrm{Ag} 3 \mathrm{P}_{3} \mathrm{O}_{9} \cdot \mathrm{H}_{2} \mathrm{O} \longrightarrow$

$\mathrm{MnAg}_{4}\left(\mathrm{P}_{3} \mathrm{O}_{9}\right)_{2} \cdot 6 \mathrm{H}_{2} \mathrm{O}+12 \mathrm{AgCl}$.

To eliminate the insoluble silver chloride, the resulting solution after filtration is kept at room temperature until the formation of polycrystalline samples of $\mathrm{MnAg}_{4}\left(\mathrm{P}_{3} \mathrm{O}_{9}\right)_{2} \cdot 6 \mathrm{H}_{2} \mathrm{O}$. The weight loss performed by slowly heating up to a temperature of $350{ }^{\circ} \mathrm{C}$ confirms the compound as a hexahydrate. The polycrystalline samples are stable in air for many months under normal conditions of temperature and hygrometry [33]. 
Hamza Marouani et al., International Journal of Emerging Trends in Engineering Research, 8(7), July 2020, 4784 - 4798

\section{9. $\mathrm{Mn}_{3}\left(\mathrm{P}_{3} \mathrm{O}_{9}\right)_{2} .10 \mathrm{H}_{2} \mathrm{O}$}

Polycrystalline samples of the title compound, $\mathrm{Mn}_{3}\left(\mathrm{P}_{3} \mathrm{O}_{9}\right)_{2} \cdot 10 \mathrm{H}_{2} \mathrm{O}$ [34], were prepared by adding slowly dilute cyclotriphosphoric acid to an aqueous solution of manganese carbonate, according to the following chemical reaction:

$$
\begin{aligned}
& 2 \mathrm{H}_{3} \mathrm{P}_{3} \mathrm{O}_{9}+3 \mathrm{MnCO}_{3}+7 \mathrm{H}_{2} \mathrm{O} \longrightarrow \\
& \mathrm{Mn}_{3}\left(\mathrm{P}_{3} \mathrm{O}_{9}\right)_{2} \cdot 10 \mathrm{H}_{2} \mathrm{O}+3 \mathrm{CO} 2
\end{aligned}
$$

The so-obtained solution was then slowly evaporated at room temperature until polycrystalline samples of

$\mathrm{Mn}_{3}\left(\mathrm{P}_{3} \mathrm{O}_{9}\right)_{2} \cdot 10 \mathrm{H}_{2} \mathrm{O}$ were obtained. The cyclotriphosphoric acid used in this Reaction was prepared from an aqueous solution of $\mathrm{Na}_{3} \mathrm{P}_{3} \mathrm{O}_{9}$ passed through an ion-exchange resin "Amberlite IR 120" [35].

\subsubsection{Sample characterization}

\section{X-ray powder diffraction}

The calculation of the parameters and the analysis of the $\mathrm{X}$-ray diffractogram enabled us to verify the purity of the synthesized product. The unit-cell parameters of these triphosphates are collected in table 9.

Table 9: Main Crystallographic Data for the

\begin{tabular}{|c|c|c|c|c|c|c|}
\hline Formula & $\begin{array}{l}\mathbf{a}(\AA) \\
\alpha\left({ }^{\circ}\right)\end{array}$ & $\begin{array}{l}\mathbf{b}(\stackrel{\AA}{\mathbf{A}}) \\
\beta\left(\left(^{\circ}\right)\right.\end{array}$ & $\begin{array}{l}\mathbf{c}(\stackrel{\AA}{\AA}) \\
\gamma\left({ }^{\circ}\right)\end{array}$ & S.G. & $\mathbf{Z}$ & References \\
\hline $\mathrm{MnNH}_{4} \mathrm{P}_{3} \mathrm{O}_{9}$ & 7.357 & 12.186 & 9.390 & Pmcm & 4 & [27] \\
\hline $\mathrm{MnBa}_{2}\left(\mathrm{P}_{3} \mathrm{O}_{9}\right)_{2} \cdot 6 \mathrm{H}_{2} \mathrm{O}$ & $\begin{array}{c}7.534 \\
107.93\end{array}$ & $\begin{array}{l}11.898 \\
100.36\end{array}$ & $\begin{array}{c}13.053 \\
95.78\end{array}$ & P-1 & 4 & [28] \\
\hline $\mathrm{MnCa}_{2}\left(\mathrm{P}_{3} \mathrm{O}_{9}\right)_{2} \cdot 10 \mathrm{H}_{2} \mathrm{O}$ & 9,631 & $\begin{array}{l}18.173 \\
109.44\end{array}$ & 7.976 & $\mathrm{P} 2{ }_{1} / \mathrm{n}$ & 2 & [29] \\
\hline $\mathrm{MnCa}_{2}\left(\mathrm{P}_{3} \mathrm{O}_{9}\right)_{2}$ & 7.392 & 7,392 & 20.134 & $\mathrm{P}-31 \mathrm{c}$ & 2 & [29] \\
\hline $\mathrm{MnSr}_{2}\left(\mathrm{P}_{3} \mathrm{O}_{9}\right)_{2} \cdot 4 \mathrm{H}_{2} \mathrm{O}$ & $\begin{array}{c}6.653 \\
103.37\end{array}$ & $\begin{array}{l}7.110 \\
95.81\end{array}$ & $\begin{array}{l}5.123 \\
93.04\end{array}$ & P-1 & 1 & [30] \\
\hline $\begin{array}{c}\mathrm{Mn} \\
\left(\mathrm{NH}_{4}\right)_{4}\left(\mathrm{P}_{3} \mathrm{O}_{9}\right)_{2} \cdot 6 \mathrm{H}_{2} \mathrm{O}\end{array}$ & 13,178 & $\begin{array}{l}11.030 \\
126.76\end{array}$ & 9.965 & $\mathrm{C} 2 / \mathrm{m}$ & 2 & [31] \\
\hline $\mathrm{Mn}_{3}\left(\mathrm{P}_{3} \mathrm{O}_{9}\right)_{2} \cdot 10 \mathrm{H}_{2} \mathrm{O}$ & 9.631 & $\begin{array}{c}18,173 \\
109,438\end{array}$ & 7,976 & $\mathrm{P} 2{ }_{1} / \mathrm{n}$ & 2 & [34] \\
\hline
\end{tabular}
cyclotriphosphate associated to manganese.

2. Characterization by infrared vibration spectrometry of cyclotriphosphate decahydrate of manganese and dicalcium, $\mathrm{MnCa}_{2}\left(\mathrm{P}_{3} \mathrm{O}_{9}\right)_{2} \cdot \mathbf{1 0 H}_{2} \mathrm{O}$

The packaging used for all spectra of infrared absorption is the same: $1 \mathrm{mg}$ of product in $200 \mathrm{mg}$ of $\mathrm{KBr}$ intimately crushed for the manufacture of a pellet at room temperature and at atmospheric pressure.

The absorption spectrum IR of $\mathrm{MnCa}_{2}\left(\mathrm{P}_{3} \mathrm{O}_{9}\right)_{2} \cdot 10 \mathrm{H}_{2} \mathrm{O}$ [36] (Figure 4) contains:
- In the spectral region $4000-3000 \mathrm{~cm}^{-1}$, characteristic of $\mathrm{OH}$ valence bands, a single wideband around 3450 $\mathrm{cm}-1$ accompanied by a shoulder at $3290 \mathrm{~cm}^{-1}$.

- In the range, $1700-1600 \mathrm{~cm}^{-1}$ characteristic of water deformation bands, a strong intensity band at $1671 \mathrm{~cm}^{-1}$, accompanied by a shoulder at $1690 \mathrm{~cm}^{-1}$

- between 1400 and $640 \mathrm{~cm}^{-1}$, the characteristic domain of the valence bands of the $\mathrm{P}_{3} \mathrm{O}_{9}{ }^{3-}$ cycle, possibly of the water-cycle interaction and rotations of the water molecules, seven bands are observed. Four broad bands of high intensity all appear as a doublet of frequency: $\left(1280,1264 \mathrm{~cm}^{-1}\right),\left(1132,1105 \mathrm{~cm}^{-1}\right)$, $\left(1025,987 \mathrm{~cm}^{-1}\right.$ and $\left(791,753 \mathrm{~cm}^{-1}\right)$. All the other bands are fine and of average intensity, one appears doubled at 685 $\mathrm{cm}^{-1}-645 \mathrm{~cm}^{-1}$ and two others are observed at $1162 \mathrm{~cm}^{-1}$ and $868 \mathrm{~cm}^{-1}$. The symmetry of the $\mathrm{P}_{3} \mathrm{O}_{9}{ }^{3-} \mathrm{cm}^{-1}$ ring in this compound is lower than the symmetry $\mathrm{C} 3 \mathrm{~h}$ or $\mathrm{D} 3 \mathrm{~h}$.

- Between 640 and $400 \mathrm{~cm}^{-1}$, the domain characterizing the deformation vibrations of oxygenates outside the cycle $\left(\delta \mathrm{OPO}^{-}+\delta \mathrm{POP}\right)$ exist two frequencies respectively located at $522 \mathrm{~cm}^{-1}$ and $476 \mathrm{~cm}^{-1}$.

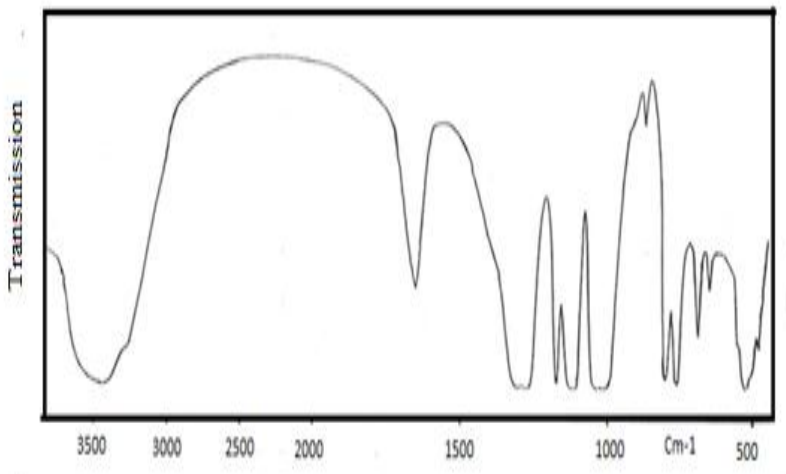

Figure 4: IR absorption spectrum of $\mathrm{MnCa}_{2}\left(\mathrm{P}_{3} \mathrm{O}_{9}\right)_{2} \cdot 10 \mathrm{H}_{2} \mathrm{O}$

2. $\mathrm{P}_{4} \mathrm{O}_{12}$

\subsubsection{Sample preparation}

\section{$1 . \mathrm{Mn}_{2} \mathrm{P}_{4} \mathrm{O}_{12}$}

The total dehydration of $\mathrm{Mn}\left(\mathrm{NH}_{4}\right)_{4}\left(\mathrm{P}_{3} \mathrm{O}_{9}\right)_{2} \cdot 6 \mathrm{H}_{2} \mathrm{O}$ [37] leads at $500^{\circ} \mathrm{C}$ to the anhydrous form, cyclotetraphosphate $\mathrm{Mn}_{2} \mathrm{P}_{4} \mathrm{O}_{12}$. It's the first time that the dehydration and the calcination of a cyclotriphosphate $\left(\mathrm{P}_{3} \mathrm{O}_{9}\right)$ leads to a cyclotetraphosphate $\left(\mathrm{P}_{4} \mathrm{O}_{12}\right), \mathrm{Mn}_{2} \mathrm{P}_{4} \mathrm{O}_{12}[37,38]$ (figure 5).

\section{2. $\mathrm{MnFeP}_{4} \mathrm{O}_{12}$}

The binary $\mathrm{Mn}_{0.5} \mathrm{Fe}_{0.5}\left(\mathrm{H}_{2} \mathrm{PO}_{4}\right)_{2} \cdot \mathrm{xH}_{2} \mathrm{O}$ compound was prepared by solution precipitation method using the metal sources of Mn(c; complexometric) (99.99\%, Merck), Fe (c; complexometric), (99.99\%, Fluka) and phosphoric acid (86.4\% (w/w) $\mathrm{H}_{3} \mathrm{PO}_{4}$, Merck) as starting materials. In typical procedure, $0.5494 \mathrm{~g}$ of $\mathrm{Mn}(\mathrm{c})$ and $0.5593 \mathrm{~g}$ of $\mathrm{Fe}(\mathrm{c})$ were 
Hamza Marouani et al., International Journal of Emerging Trends in Engineering Research, 8(7), July 2020, 4784 - 4798

dissolved in $70 \% \mathrm{H}_{3} \mathrm{PO}_{4}\left(81.02 \mathrm{~mL}\right.$ of $86.4 \%$ (w/w) $\mathrm{H}_{3} \mathrm{PO}_{4}$ in $18.98 \mathrm{~mL}$ of water) with continuous stirring at ambient temperature. The resulting solution was stirred until $\mathrm{H}_{2}(\mathrm{~g})$ was completely evolved (15-30 $\mathrm{min})$ and the nearly dry precipitates were obtained, then $10 \mathrm{~mL}$ of acetone was added to allow highly crystalline product to be developed. The prepared solid was filtered by suction pump, washed with acetone and dried in air. The manganese and iron contents of $\mathrm{Mn}_{0.5} \mathrm{Fe}_{0.5}\left(\mathrm{H}_{2} \mathrm{PO}_{4}\right)_{2} \cdot \mathrm{xH}_{2} \mathrm{O}$ compound were determined by dissolving in $0.0126 \mathrm{M}$ hydrochloric acid using atomic absorption spectrophotometry (AAS, Perkin-Elmer, Analyst100). The phosphorus content was determined by colorimetric analysis of the molybdophosphate complex. The water content was determined by heating at $500 \mathrm{C}$ in the furnace for $3 \mathrm{~h}$ and the manganese iron cyclo-tetraphosphates $\left(\mathrm{MnFeP}_{4} \mathrm{O}_{12}\right)$ were obtained as the final decomposition yield [39].

This process formally could be presented as:

$$
\begin{gathered}
\mathrm{Mn}_{0,5} \mathrm{Fe}_{0.5}\left(\mathrm{H}_{2} \mathrm{PO}_{4}\right)_{2} \cdot \mathrm{xH}_{2} \mathrm{O} \rightarrow \mathrm{Mn}_{0,5} \mathrm{Fe}_{0.5}\left(\mathrm{H}_{2} \mathrm{PO}_{4}\right)_{2}+\mathrm{H}_{2} \mathrm{O}(1) \\
\mathrm{Mn}_{0,5} \mathrm{Fe}_{0.5}\left(\mathrm{H}_{2} \mathrm{PO}_{4}\right)_{2} \rightarrow \mathrm{Mn}_{0,5} \mathrm{Fe}_{0.5}\left(\mathrm{H}_{2} \mathrm{P}_{2} \mathrm{O}_{7}\right)+\mathrm{H}_{2} \mathrm{O}(2) \\
\mathrm{Mn}_{0,5} \mathrm{Fe}_{0.5}\left(\mathrm{H}_{2} \mathrm{P}_{2} \mathrm{O}_{7}\right) \rightarrow(1 / 2) \mathrm{MnFeP}_{4} \mathrm{O}_{12}+\mathrm{H} 2 \mathrm{O}(3)
\end{gathered}
$$

\subsubsection{Sample characterization}

\section{X-ray powder diffraction}

The calculation of the unit-cell parameters and the analysis of the X-ray diffraction patterns enabled us to verify the purity of of these cycloriphosphates are collected in table 10.

Table 10: Main Crystallographic Data for the Cyclotetraphosphates associated with manganese. the synthesized product $\mathrm{Mn}_{2} \mathrm{P}_{4} \mathrm{O}_{12}$. The unit-cell parameters

Table 11: Characterization of $\mathrm{P}_{4} \mathrm{O}_{12}{ }^{4-}$ by IR vibration

\begin{tabular}{|c|c|}
\hline & \\
Frequencies $\left(\mathbf{c m}^{-1}\right)$ & Vibrations \\
\hline 1315 & $v_{\text {as }}$ OPO $^{-}$ \\
1301 & \\
1275 & \\
1116 & $v_{\mathrm{s}} \mathrm{OPO}^{-}$ \\
1101 & \\
1048 & $v_{\mathrm{as}} \mathrm{POP}$ \\
1017 & \\
733 & \\
712 & $v_{\mathrm{s}} \mathrm{POP}$ \\
669 & \\
\multicolumn{2}{|c}{} \\
\hline
\end{tabular}

3. $\mathrm{P}_{6} \mathrm{O}_{18}{ }^{6-}$

$\mathrm{Mn}_{3} \mathrm{P}_{6} \mathrm{O}_{18} \cdot 6 \mathrm{H}_{2} \mathrm{O}$ [40] was prepared by reaction of $\mathrm{Ag}_{6} \mathrm{P}_{6} \mathrm{O}_{18}$ with $\mathrm{MnCl}_{2}$. It crystallizes in the rhombohedral space group

\begin{tabular}{|c|c|c|c|c|c|c|}
\hline Formula & $\begin{array}{l}\mathbf{a}(\stackrel{\AA}{\mathbf{\Lambda}}) \\
\alpha\left(\left(^{\circ}\right)\right.\end{array}$ & $\begin{array}{l}\mathbf{b}(\AA) \\
\beta\left(\left(^{\circ}\right)\right.\end{array}$ & $\begin{array}{l}\text { c( }(\AA) \\
\gamma\left(\left(^{\circ}\right)\right.\end{array}$ & S.G. & $\mathbf{Z}$ & $\begin{array}{l}\text { Referen } \\
\text { ces }\end{array}$ \\
\hline $\mathrm{Mn}\left(\mathrm{PO}_{3}\right)_{3}$ & 9.703 & 10.667 & 6.362 & Pnma & 4 & [42] \\
\hline $\mathrm{MnBa}\left(\mathrm{PO}_{3}\right)_{4}$ & 14,69 & $\begin{array}{l}9,147 \\
90,57\end{array}$ & 7,201 & $\mathrm{P} 2{ }_{1} / \mathrm{n}$ & 4 & [43] \\
\hline $\mathrm{Li}_{2} \mathrm{Mn}\left(\mathrm{PO}_{3}\right)_{4}$ & 9.4295 & 9.2755 & 10.0972 & Pnma & 4 & [44] \\
\hline$\left(\mathrm{NH}_{4}\right)_{2} \mathrm{Mn}\left(\mathrm{PO}_{3}\right)_{4}$ & 11,30 & $\begin{array}{l}12,99 \\
101.5\end{array}$ & 7,839 & $\mathrm{P} 2{ }_{1} / \mathrm{n}$ & 4 & [45] \\
\hline $\mathrm{Cs}_{2} \mathrm{Mn}\left(\mathrm{PO}_{3}\right)_{4}$ & 7,9762 & $\begin{array}{c}13,24.91 \\
101,97\end{array}$ & 11,5462 & $\mathrm{P} 2 / \mathrm{n}$ & 4 & [46] \\
\hline $\begin{array}{c}\mathrm{Mn}_{2}\left(\mathrm{O}_{3} \mathrm{P}-\mathrm{C}_{4} \mathrm{H}_{2} \mathrm{~S}-\mathrm{PO}_{3}\right) .2 \\
\mathrm{H}_{2} \mathrm{O}\end{array}$ & 11.60 & $\begin{array}{c}4.943 \\
107.22\end{array}$ & 19.614 & $\mathrm{P} 2$ & 4 & [47] \\
\hline $\mathrm{MnNH}_{4}\left(\mathrm{PO}_{3}\right)_{3}$ & 6,771 & 6,771 & 10,026 & P-6c2 & 4 & [48] \\
\hline $\mathrm{LiMn}\left(\mathrm{PO}_{3}\right)_{3}$ & 8.364 & $\begin{array}{l}8.561 \\
101.4\end{array}$ & 8.6600 & $\mathrm{P} 2_{1}$ & 4 & [49] \\
\hline
\end{tabular}
R3 with $\mathrm{Z}=2$.

Table 12: Main Crystallographic Data for the

\subsection{Long chain polyphosphates $\left(\mathrm{PO}_{3}{ }^{-}\right)_{n}$}

\section{Characterization of $\mathrm{P}_{4} \mathrm{O}_{12}{ }^{4-}$ in $\mathrm{Mn}_{2} \mathrm{P}_{4} \mathrm{O}_{12}$ by IR vibration spectrometry}

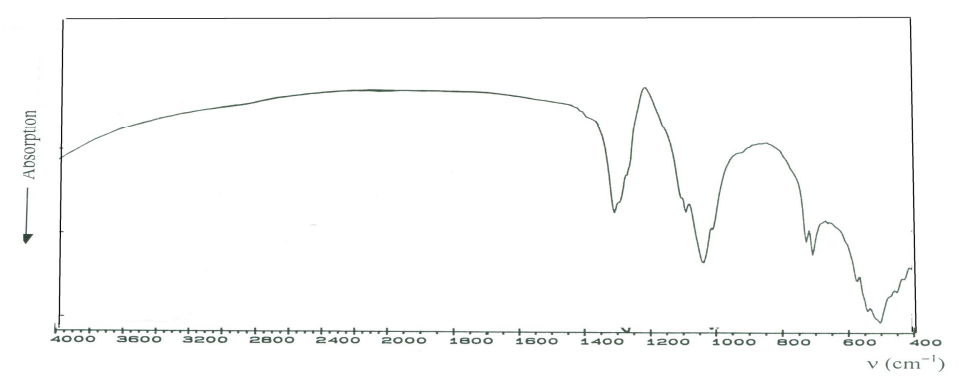

Figure 5: IR absorption spectrum of $\mathrm{Mn}_{2} \mathrm{P}_{4} \mathrm{O}_{12}$

\subsubsection{Sample preparation}

\section{1. $\mathrm{Mn}\left(\mathrm{PO}_{3}\right)_{3}$}

The method of preparation used consists of heating a mixtur e of manganese carbonate in an excess of orthophosphoric a cid to $450-500$

$\mathrm{C}$ for one fi three days at the concentration (1 $\mathrm{mol}$ of $\mathrm{MnCO}$

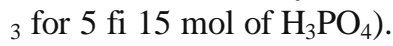

The crystals have a characteristic red-violet colour that clearly distinguishes them from bivalent manganese téramétaphosphate, which is a pale pink colour (Beucher \&amp, Grenier1968). Both types of compote can crystallize at the same time. Their crystalline morphology is also different: the Manganous salts appear as octahedrons or needles growing in dendrites, the Manganous salts as prisms ( It 
should be noted that if orthophosphorique acid is replaced by biammonium phosphate only the latter crystallises, the medium not being sufficiently acidic to stabilise the manganic salts) [42].

\section{2. $\quad \mathrm{BaMn}\left(\mathrm{PO}_{3}\right)_{4}$}

These four salts are easily prepared by calcination of a mixtu re in stoichiometric proportions of biammonium monophosp hate, barium carbonate and bivalent m6tal carbonate corresp onding to the different formulae of the compounds. The heat ing temperatures are $700^{\circ} \mathrm{C}$ for $\mathrm{MnBa}\left(\mathrm{PO}_{3}\right)_{4}, \mathrm{CdBa}\left(\mathrm{PO}_{3}\right)_{4}$ a nd $\mathrm{CaBa}\left(\mathrm{PO}_{3}\right)_{4}$ and $400^{\circ} \mathrm{C}$ for $\mathrm{HgBa}\left(\mathrm{PO}_{3}\right)_{4}$ [43].

\section{3. $\mathrm{Li}_{2} \mathrm{Mn}\left(\mathrm{PO}_{3}\right)_{4}$}

The polyphosphate $\mathrm{Li}_{2} \mathrm{Mn}\left(\mathrm{PO}_{3}\right)_{4}$ was synthetised and its structure characterized from powder diffraction data by Averbuch-Pouchot \& Durif [J. Appl. Cryst. (1972), 5, 307308]. These authors showed that the structure of this phosphate is isotypic to that of $\mathrm{Li}_{2} \mathrm{Cd}\left(\mathrm{PO}_{3}\right)_{4}$, as confirmed by the present work. The structure is built from infinite zigzag polyphosphate chains, [(PO3)], extending along [010]. These polyphosphate chains are connected by sharing vertices with MnO6 octahedra (site symmetry .m.) and $\mathrm{Li}_{2} \mathrm{O}_{7}$ polyhedra, which form also chains parallel to [010]. Adjacent chains are linked by common vertices of polyhedra in such a way as to form porous layers parallel to (100). The three-dimensional framework delimits empty channels extending along [010] [44].

\section{3. $\mathrm{Mn}\left(\mathrm{NH}_{4}\right)_{2}\left(\mathrm{PO}_{3}\right)_{4}$}

The preparation of all these compounds can be schematized by the following reaction:

$\mathrm{M}^{\mathrm{II}} \mathrm{Co}_{3}+4\left(\mathrm{NH}_{4}\right)_{2} \mathrm{HPO}_{4} \longrightarrow \mathrm{M}^{\mathrm{II}}\left(\mathrm{NH}_{4}\right)_{2}\left(\mathrm{PO}_{3}\right)_{4}+6 \mathrm{NH}_{3}+$ $5 \mathrm{H}_{2} \mathrm{O}+\mathrm{CO}_{2}$

The method used is to take a very large excess of biammonium phosphate and heat the mixture $350^{\circ} \mathrm{C}$ for one day. Crystals are obtained in the form of bipyramidal prisms with an almost square cross-section; the axis of the prism corresponds to the c-direction of the monoclinic unit cell. Chromatographic analysis shows that they are long chain polyphosphates [45].

\section{4. $\mathrm{Cs}_{2} \mathrm{Mn}\left(\mathrm{PO}_{3}\right)_{4}$}

5. As starting compounds were $\mathrm{Cs}, \mathrm{CO}, \mathrm{MnO}$ and $\mathrm{H}, \mathrm{PO}$, $(85 \%)$, all p. a. Merck, used. Weighed quantities of the starting compounds, corresponding to a molar ratio Cs: $\mathrm{Mn}: \mathrm{P}=3: 1: 5$, were left for 7 days at $500{ }^{\circ} \mathrm{C}$ in an open porcelain crucible. The by-product resulting, in contrast to Cs, Mn (PO,), water-soluble (CsPO,), was separated by leaching (ultrasonic bath, $35 \mathrm{kHz}, 30 \mathrm{~min}$.) With water from the reaction product. After Biltrieren and washing we obtained a blue-blue powder, already for an X-ray structure analysis contained suitable single crystals [46].
6. $\mathrm{Mn}_{2}\left(\mathrm{O}_{3} \mathrm{P}-\mathrm{C}_{4} \mathrm{H}_{2} \mathrm{~S}-\mathrm{PO}_{3}\right) .2 \mathrm{H}_{2} \mathrm{O}$

7. Hydrothermal Synthesis of $\mathrm{Mn}_{2}\left(\mathrm{O}_{3} \mathrm{P}-\mathrm{C}_{4} \mathrm{H}_{2} \mathrm{~S}-\mathrm{PO}_{3}\right) \cdot 2 \mathrm{H}_{2} \mathrm{O}$ 3. Thiophene-2,5-diphosphonic acid $2(0.05 \mathrm{~g}, 0.2$ $\mathrm{mmol})$, urea $(0.024 \mathrm{~g}, 0.4 \mathrm{mmol})$, and $\mathrm{Mn}\left(\mathrm{NO}_{3}\right)_{2} \cdot 6 \mathrm{H}_{2} \mathrm{O}$ $(0.118 \mathrm{~g}, 0.4 \mathrm{mmol})$ were dissolved in distilled water $(15$ $\mathrm{mL}$ ). The resulting solution was placed in a PTFE insert of $50 \mathrm{~mL}$. After stirring $15 \mathrm{~min}$ the $\mathrm{pH}$ of the mother solution (pHinitial) was 1.66. The insert was then transferred in a Berghof pressure digestion vessel and heated from room temperature to $140{ }^{\circ} \mathrm{C}$ in $20 \mathrm{~h}$, heated $40 \mathrm{~h}$ at $140{ }^{\circ} \mathrm{C}$, and cooled to room temperature in $40 \mathrm{~h}$. At the opening of the PTFE insert the $\mathrm{pH}$ of the solution (pH final) was 4.13, and the final material, obtained as light brown crystals with suitable size for structure resolution on a single crystal, was isolated by filtration, washed with water rinsed with absolute ethanol, and dried in air [47].

\subsubsection{Sample characterization}

\section{X-ray powder diffraction}

The calculation of the unit-cell parameters and the analysis of the X-ray diffractogram enabled us to verify the purity of the synthesized product. The mesh parameters of these Triphosphates are collected in table 13

Table 13: Main Crystallographic Data for the polyphosphates associated to manganese.

\begin{tabular}{|c|c|c|c|c|c|c|}
\hline Formula & $\begin{array}{l}a(\AA) \\
\alpha\left({ }^{\circ}\right)\end{array}$ & $\begin{array}{l}\mathbf{b}(\stackrel{\AA}{\mathbf{A}}) \\
\beta\left({ }^{\circ}\right)\end{array}$ & $\begin{array}{l}\mathbf{c}(\stackrel{\circ}{\mathbf{A}}) \\
\gamma\left({ }^{\circ}\right)\end{array}$ & S.G. & $\bar{Z}$ & References \\
\hline $\mathrm{Mn}_{3} \mathrm{P}_{6} \mathrm{O}_{18} \cdot 6 \mathrm{H}_{2} \mathrm{O}$ & 14,836 & 14,836 & 15,781 & R-3 & 2 & {$[40]$} \\
\hline $\mathrm{Cs}_{3} \mathrm{Cd}_{3} \mathrm{Mn}\left(\mathrm{P}_{6} \mathrm{O}_{18}\right)_{2}$ & 16.201 & $\begin{array}{c}10.033 \\
127,10\end{array}$ & 12.540 & $\mathrm{C} 2 / \mathrm{m}$ & 2 & [41] \\
\hline $\mathrm{Cs}_{3} \mathrm{Zn}_{3} \mathrm{Mn}\left(\mathrm{P}_{6} \mathrm{O}_{18}\right)_{2}$ & 16.092 & $\begin{array}{c}9.832 \\
127,288\end{array}$ & 12.304 & $\mathrm{C} 2 / \mathrm{m}$ & 2 & [41] \\
\hline
\end{tabular}

S.G. Space Group

\section{Characterization of $\mathrm{P}_{3} \mathrm{O}_{9}$ in $\mathrm{Mn}\left(\mathrm{PO}_{3}\right)_{3}$ by IR vibration} spectrometry.

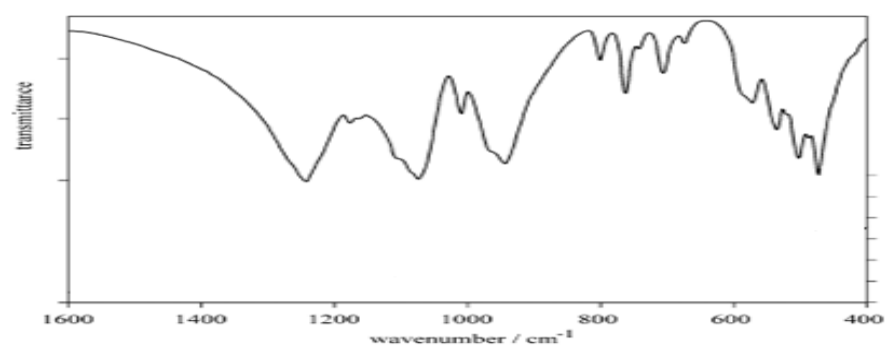

Figure 6: IR absorption spectrum of $\mathrm{MnNi}\left(\mathrm{PO}_{3}\right)_{3}$

Figure 6 shows the IR spectrum of the title compound $\mathrm{MnNi}\left(\mathrm{PO}_{3}\right)_{3}$. The IR spectrum of catena-polyphosphates is not significantly different from those of catena-oligophosphates. The only characteristic bands should be found in the region between 800 and $650 \mathrm{~cm}^{-1}$, where the number of bands should correspond to the periodicity of the phosphate chain. Unfortunately, this holds quite reliably only for low chain periodicities. In $\mathrm{Mn}\left(\mathrm{PO}_{3}\right)_{2}$, the characteristic frequencies of catena-polyphosphate chains suchas the vas $\left(\mathrm{PO}_{2}\right)$ are detected between 1200 and $1310 \mathrm{~cm}-1$ with a 
Hamza Marouani et al., International Journal of Emerging Trends in Engineering Research, 8(7), July 2020, 4784 - 4798

maximum at $1243 \mathrm{~cm}^{-1}$, the very intense vas(POP)at 944 $\mathrm{cm}^{-1}$ and $v$ (POterm) ranging from 1019 up to $1100 \mathrm{~cm}^{-1}$. Thus the observed vibrational data are in good agreement with the expected values [50]. It is worth noticing that long chain polyphosphates are good corrosion inhibitors [51-55].

\section{CONCLUSION}

We have collected crystallographic data for manganese-associated condensed phosphates and monophosphates with known structures. Various condensed phosphates and monophosphates, especially anions, have been characterized by infrared vibration spectrometry. Different methods for the preparation of condensed phosphates have been cited here (classical methods, thermal methods, Boulle process, flow methods and ion exchange resins). And also, we have collected crystallographic data for condensed phosphates and monophosphates associated to strontium with known structures. Until today there are no condensed phosphates studied with the following anions: cyclophosphates $\mathrm{P}_{\mathrm{n}} \mathrm{O}_{3 \mathrm{n}}{ }^{\mathrm{n}-}$ (3 types of anions: $\mathrm{P}_{5} \mathrm{O}_{15}{ }^{5-}, \mathrm{P}_{8} \mathrm{O}_{24}{ }^{8-}$, $\left.\mathrm{P}_{12} \mathrm{O}_{36}{ }^{12-}\right)$ and oligophosphates $\left(\mathrm{P}_{\mathrm{n}} \mathrm{O}_{3 \mathrm{n}+1}\right)^{(\mathrm{n}+2)-}$ (3 types of anions : $\left.\mathrm{P}_{3} \mathrm{O}_{10}{ }^{5-}, \mathrm{P}_{4} \mathrm{O}_{13}{ }^{6-}, \mathrm{P}_{5} \mathrm{O}_{16}{ }^{7-}\right)$.

\section{REFERENCES}

[1] M. Yousuf, S. Jabeen, M. Shahi, M. Khan, I. Shakir, M.Warsi. Magnetic and electrical properties of yttrium substituted manganese ferrite nanoparticles prepared via micro-emulsion route. Results in Physics Volume 16, 102973.2020 , DOI

https://doi.org/10.1016/j.rinp.2020.102973

[2] P. Anschutz, K. Dedieu, F. Desmazes, G. Chaillou, Speciation, oxidation state, and reactivity of particulate manganese in marine sediments.

Chemical Geology Volume 218, Issues 3-4, Pages 265-279, 2005

DOI : https://doi.org/10.1016/j.chemgeo.2005.01.008

[3] E. R. Sholkovitz, D. Copland The coagulation, solubility and adsorption properties of $\mathrm{Fe}, \mathrm{Mn}, \mathrm{Cu}, \mathrm{Ni}, \mathrm{Cd}, \mathrm{Co}$ and humic acids in a river water Geochimica and Cosmochimica Acta Volume 45, Issue 2, Pages 181-189, 1981

DOI: https://doi.org/10.1016/0016-7037(81)90161-7

[4] G. J. Nieuwenhuys Magnetic behaviour of cobalt, iron and manganese dissolved in palladium Journal Advances in Physics Volume 24 - Issue 4, 1975

DOI :https://doi.org/10.1080/00018737500101461

[5] S. Zerraf, M. Belhabra , M. Tridane and S. Belaaouad. Chemical preparations, crystal data for monophosphates and condensed phosphates associated to barium and IR studies of their anions.

International Journal of Advanced Research (IJAR) ISSN 2320-5407, 2019

DOI : http://dx.doi.org/10.21474/IJAR01/8432
[6] B. Boochom, C. Danvirtual A simple synthesis and thermal decomposition kinetics of $\mathrm{MnHPO}_{4} \cdot \mathrm{H}_{2} \mathrm{O}$ rod-like microparticles obtained by spontaneous precipitation route.

Journal of optoelectrnics and advanced materials Vol. 10, No.3, p 492 - 499. 2008

[7] H. Ben Yahia, E. Gaudin, J. Darriet, Structure and magnetic properties of the new phosphate $\mathrm{RbMnPO}_{4}$ Journal of Alloys and Compounds 442 74-76. 2007 DOI :https://doi.org/10.1016/j.jallcom.2006.06.110

[8] H. Pang, Z. Yan, W. Wang, Y. Wei , X. Li , J. Li , J. Chen, J. Zhang, H. Zheng, Template-free Controlled Fabrication of $\mathrm{NH}_{4} \mathrm{MnPO}_{4} \cdot \mathrm{H}_{2} \mathrm{O}$ and $\mathrm{Mn}_{2} \mathrm{P}_{2} \mathrm{O}_{7}$ Micro-Nanostructures and Study of Their Electrochemical Properties, Int. J. Electrochem. Sci 712340 - 12353. 2012

[9] W. Xuehang, W. Wenwei , L. Chen , L. Shushu, L. Sen , C. Jinchao, Synthesis of Layered Sodium Manganese Phosphate via Low-heating Solid State Reaction and Its Properties Chin. J. Chem, 28, 2394 -2398. 2010

DOI : https://doi.org/10.1002/cjoc.201190010

[10] F. Sanz, C. Parada, J. M.Rojo and C. Ruiz-Valero Synthesis, Structural Characterization, Magnetic Properties, and Ionic Conductivity of $\mathrm{Na}_{4} \mathrm{M}_{3}^{\mathrm{II}}\left(\mathrm{PO}_{4}\right)_{2}\left(\mathrm{P}_{2} \mathrm{O}_{7}\right)\left(\mathrm{M}^{\mathrm{II}} \mathrm{Mn}, \mathrm{Co}\right.$, Ni) Chem. Mater., 13, 1334-1340. 2001

DOI : https://doi.org/10.1021/cm001210d

[11] I.Korchemkin, V.Petkov, A.Markin, N.Smirnova, A.Kovalskii, N.Efimov, V.Novotortsev. Thermodynamic properties of caesium-manganese phosphate $\mathrm{CsMnPO}_{4}$, The Journal of Chemical Thermodynamics Volume 78 , pages 114-119Novembre 2014

DOI : https://doi.org/10.1016/j.jct.2014.06.012

[12] W. Massa, O. Yakubovich, O. Dimitrova. A novel modification of manganese orthophosphate $\mathrm{Mn}_{3}\left(\mathrm{PO}_{4}\right)_{2}$, Solid State Sciences 7 950-956 . 2005.

DOI:https://doi.org/10.1016/j.solidstatesciences.2005.03.005 [13] G. Fang, S. Dong, J. Zou1, X. Zeng, Synthesis and Electrochemical Properties of Fe-Doped $\mathrm{LiMnPO}_{4}$. Nanocomposite Prepared by a Hydrothermal Process in a High-Pressure Reactor, Int. J. Electrochem. Sci.11 7621 7630, 2016. DOI: 10.20964/2016.09.24.

[14] D. Visser, S. G. Carling, P. Day, and J. Deportes Magnetic structure of $\mathrm{KMnPO}_{4} \cdot \mathrm{H}_{2} \mathrm{O}$, Journal of Applied Physics volume 69, Issue 860161991.

DOI : https://doi.org/10.1063/1.347797

[15] E. Majdi, S. Zerraf, H. Marouani, S. El Makhloufy, M. Belhabra, A. Ouasri, Y. Naimi and S. Belaaouad, Structural and vibrational study of titanium Monophosphates $\mathrm{Na}_{0.5} \mathrm{M}_{0.25} \mathrm{Ti}_{2}\left(\mathrm{PO}_{4}\right)_{3}(\mathrm{M}=\mathrm{Mn}, \mathrm{Ni})$, Mediterranean Journal of Chemistry, 9(5), 355-362 2019

DOI: http://dx.doi.org/10.13171/mjc01911281083emm

.[16] M. Bettach, Y. Ennaciri, M. Touaiher and K. Benkhouja, Structure refinement, EPR, Specific magnetic heat and magnetic properties of ZnMnP2O7 diphosphate, Moroccan Journal of Chemistry ISSN: 2351-812. Vol $7 \mathrm{~N}^{\circ} 2$ 2019

[17] L. Dogan and M. Eanes Crystal structure of distrontium manganese (III) tetraoxophosphate heptaoxodiphosphate, $\mathrm{Sr}_{2} \mathrm{Mn}\left[\mathrm{PO}_{4}\right]\left[\mathrm{P}_{2} \mathrm{O}_{7}\right], \mathrm{Z}$. Kristallogr. NCS 222 89-90 (2007) 
Hamza Marouani et al., International Journal of Emerging Trends in Engineering Research, 8(7), July 2020, 4784 - 4798

DOI: 10.1524 / ncrs.2007.0036

[18] H.Kim, G.Yoon, I.Park, K.Park, B.Lee, J.Kim, Y.Park, S.Jung, H.Lim, D.Ahn, S.Lee and K.Kanga, Anomalous Jahn-Teller behavior in manganese-based mixed phosphate cathode for sodium ion batteries Energy \& environnemental science journal, Numéro 11, 28 October 2015

DOI :https://doi.org/10.1039/C5EE01876E

[19] K. Benkhouja, M. Zahir and A. Sadel. Crystal chemistry single Cristal x-ray structure and mangnetism of nickel manganese pyrophosphate, Materials Research Bulletin 30 (1): 49-55 - janvier 1995 .

DOI: $10.1016 / 0025-5408(94) 00106-5$

[20] B. Boonchom and C. Danvirutai, Synthesis of $\mathrm{MnNiP}_{2} \mathrm{O}_{7}$ and Noniso thermal Decomposition Kinetics of a New Binary $\mathrm{Mn}_{0.5} \mathrm{Ni}_{0.5} \mathrm{HPO}_{4} \cdot \mathrm{H}_{2} \mathrm{O}$ Precursor Obtained from a Rapid Coprecipitation at Ambient Temperature Ind. Eng. Chem. Res, 47, 5976-5981. July 2, 2008

DOI :https://doi.org/10.1021/ie800484r

[21] R. Baies, V. Pralong, V. Caignaert and B. Raveau. The Trivalent Manganese Hydrogenophosphate $\operatorname{LiMn}\left(\mathrm{H}_{2} \mathrm{P}_{2} \mathrm{O}_{7}\right)_{2}$, A Chain-Like Structure Zeitschrift für anorganische und allgemeine Chemie 638(12-13) October (2012)

DOI :https://doi.org/10.1002/zaac.201200101

[22] R. Adams, R. Layland, C. Payen., New manganese pyrophosphates: The syntheses, crystallographic characterization and magnetic properties of $\mathrm{BaMnP}_{2} \mathrm{O}_{7}$ and $\mathrm{CaMnP}_{2} \mathrm{O}_{7}$ Polyhedron Volume 14, numéros 23-24, pages 3473-3480 Décembre 1995

DOI :https://doi.org/10.1016/0277-5387(95)00205-7

[23] M. Belhabra, S. Zerraf, A. Kheireddine, A. Altomare, M. Tridane, A. Ouasri, M. Radid, S. Belaaouad. Structural and vibrational study of diphenylhydrazine dihydrogenophosphate single crystal (C6H9N2)2H2P2O7 (DPHDP) . Chemical Data Collections VOLUMES 13-14, PAGES 73-83MARCH 2018

DOI: $10.1016 /$ j.cdc.2018.01.002

[24] K. Brouzi, A. Ennaciri, F. Capitelli, V. Valentini, M. Harcharras. Vibrational Study of Manganese Ammonium Dihydrogendiphosphate Hydrated $\mathrm{Mn}_{0.5} \mathrm{NH}_{4} \mathrm{H}_{2} \mathrm{P}_{2} \mathrm{O}_{7} \cdot \mathrm{H}_{2} \mathrm{O}$. Phosphorus, Sulfur, and Silicon, 180:545-553, 2005.

DOI: 10.1080/104265090517307

[25] J. Bennazha, A. El-Maadi, Ali Boukharia and Elizabeth M. Holt $\mathrm{NaMn}_{6} \quad\left(\mathrm{P}_{2} \mathrm{O}_{7}\right)_{2}\left(\mathrm{P}_{3} \mathrm{O}_{10}\right)$ and $\mathrm{KCd}_{6}$ $\left(\mathrm{P}_{2} \mathrm{O}_{7}\right)_{2}\left(\mathrm{P}_{3} \mathrm{O}_{10}\right)$ Acta Crystallographica Section C Crystal Structure Communications 58(6) June 2002

DOI: $10.1016 /$ j.cdc.2018.01.002

[26] M.Belhabra, I.Fahim, A.Atibi, K.El Kababi, A.Ouasri, S.Zerraf, M.Tridane, M.Radid, and S.Belaaouad

Vibrational study and thermal behavior of dihydrogeno triphosphate trihydrate of 4-aminobenzoic acid and its anhydrous new form fertilizer type NP

Mediterranean Journal of Chemistry, 8(4), 270-282, 2019

DOI: $10.13171 / \mathrm{mjc} 841905308 \mathrm{mb}$

[27] G.F. Levchik , S.V. Levchik, P.D. Sachok, A.F. Selevich, A.S. Lyakhov, A.I. Lesnikovich , Thermal behaviour of ammonium polyphosphate-inorganic compound mixtures. Part 2. Manganese dioxide Thermochimica Acta 257 117-125 (1995)

DOI :https://doi.org/10.1016/0040-6031(94)02210-F

[28] R. Oubouaza, M. Tridane, H. Marouani, M. Belhabra, S. Zerraf, S. Belaaouad, Infrared Vibration and Thermal Behavior of a New Cyclotriphosphate $\mathrm{MnBa}_{2}\left(\mathrm{P}_{3} \mathrm{O}_{9}\right)_{2} \cdot 6 \mathrm{H}_{2} \mathrm{O}$ International Journal of Recent Technology and Engineering (IJRTE) ISSN: 2277-3878, Volume-8 Issue-4, November 2019.

DOI: 10.35940/ijrte.D4440.118419

[29] H. Marouani, M. Tridane, El. M. Majdi, S. Zerraf, M. Belhabra, S. Belaaouad, Engineering Techniques applied for studies by Infrared vibration, crystallographic characterization and Thermal Behavior of two new cyclotriphosphates, International Journal of Emerging Trends in Engineering Research. Volume 8, No.1 January 2020

DOI :https://doi.org/10.30534/ijeter/2020/30812020

[30] S.El Makhloufy, M.Tridane, E.Majdi, H.Marouani, S.Zerraf, M.Belhabra, A.Cherqaoui and S. Belaaouad

Chemical preparation, thermal behavior and infrared studies of the new cyclotriphosphate tetrahydrate of manganese and distrontium, $\mathrm{MnSr}_{2}\left(\mathrm{P}_{3} \mathrm{O}_{9}\right)_{2} \cdot 4 \mathrm{H}_{2} \mathrm{O}$, Editerranean Journal of Chemistry, 9(4), 280-289, 2019

DOI :http://dx.doi.org/10.13171/mjc941911141082sem

[31] M. Tridane, S. Belaaouad, K. Sbai.

Chemical preparations and crystal data for eight new Condensed phosphates.

Solid State Sciences 2, 701-704, (2000)

DOI :https://doi.org/10.1016/S1293-2558(00)01081-5

[32] K. Sbai, S. Belaaouad, and K. Brouzi. Chemical Preparation, Crystallographic Data, Thermal Behavior, and IR Studies of $\mathrm{MnNa}_{4}\left(\mathrm{P}_{3} \mathrm{O}_{9}\right)_{2} \cdot 4 \mathrm{H}_{2} \mathrm{O}$ Phosphorus, Sulfur and Silicon, Vol. 177:1085-1092, 2002

DOI :https://doi.org/10.1080/10426500211703

[33] K. Sbai, A. Atibi, K. El Kababi and S. Belaaouad CHEMICAL PREPARATION AND CRYSTAL DATA FOR FOUR NEW CONDENSED PHOSPHATES

Powder Diffraction 17 (1), March 2002

DOI: https://doi.org/10.1154/1.1424262

[34] B. Gourja, M. Belhabra, M. Tridane and S. Belaaouad. Study of the structural modifications of cyclophosphates of manganese from $\mathrm{M}_{3}\left(\mathrm{P}_{3} \mathrm{O}_{9}\right)_{2} \cdot 10 \mathrm{H}_{2} \mathrm{O}$ to $\mathrm{Mn}_{2} \mathrm{P}_{4} \mathrm{O}_{12}$ during thermal behavior process by infrared spectroscopy, International Journal of Recent Scientific Research Vol. 7, Issue, 9, pp. 13462-13473, September, 2016. DOI:10.24327 / IJRSR

[35] K. Brouzi, M. Harcharras, A. Ennaciri and K. Sbai Thermal study of $\mathrm{M}_{3}^{\mathrm{II}}\left(\mathrm{P}_{3} \mathrm{O}_{9}\right)_{2} \cdot 10 \mathrm{H}_{2} \mathrm{O}\left(\mathrm{M}^{\mathrm{II}}=\mathrm{Cd}, \mathrm{Mn}, \mathrm{Ca}\right)$ Ann. Chim. Sci. Mat. 28 159-166 (2003)

DOI : https://doi.org/10.1016/S0151-9107(03)00014

[36] H. Marouani, M. Tridane, E. Majdi, S. Zerraf, M. Belhabra, S. Belaaouad. Engineering Techniques applied for studies by Infrared vibration, crystallographic 
Hamza Marouani et al., International Journal of Emerging Trends in Engineering Research, 8(7), July 2020, 4784 - 4798

characterization and Thermal Behavior of two new cyclotriphosphates

International Journal of Emerging Trends in Engineering Research Volume 8, No. 1 January 2020

DOI :https://doi.org/10.30534/ijeter/2020/30812020

[37] M. Tridane and S. Belaaouad. Chemical preparation, crystallographic characterization, vibrational study and thermal behavior of a new cyclotriphosphate $\mathrm{Mn}\left(\mathrm{NH}_{4}\right)_{4}\left(\mathrm{P}_{3} \mathrm{O}_{9}\right)_{2} \cdot 6 \mathrm{H}_{2} \mathrm{O}$ superphosphate fertilizer.

ISSN : 2028-2508 CODEN: JMESCN. J. Mater. Environ. Sci. 6 (12) 3476-3482 (2015).

[38] S. Zerraf, M. Tridane, S. Belaaouad. Interpretation of the IR Spectrum of Manganese Cyclotetraphosphate $\mathrm{Mn}_{2} \mathrm{P}_{4} \mathrm{O}_{12}$ and Vibrational Analysis of the Cycle $\mathrm{P}_{4} \mathrm{O}_{12}{ }^{4-}$ Science Arena Publications Specialty Journal of Chemistry, Vol, 4 (2): 10-17. 2019.

[39] B. Boonchom and M. Thongkam. Kinetics and Thermodynamics of the Formation of $\mathrm{MnFeP}_{4} \mathrm{O}_{12}$, J.Chem. Eng. Data 2010, 55, 211-216.

DOI :https://doi.org/10.1021/je900310m

[40] M. T. Averbuch-pouchot, A. Durif, Mechanics.Physics. Chemistry. Space sciences. Earth sciences. 1989, Vol. 309, Num 6, pp 535-537

[41] Murashova, E V, and Chudinova, N N. Synthesis and crystal structures of $\mathrm{Cs} 3 \mathrm{Mg} 3 \mathrm{In}(\mathrm{P} 6 \mathrm{O} 18) 2, \mathrm{Cs}_{3} \mathrm{Cd}_{3} \mathrm{Mn}\left(\mathrm{P}_{6} \mathrm{O}_{18}\right)_{2}$, $\mathrm{Cs}_{3} \mathrm{Zn}_{3} \mathrm{Mn}\left(\mathrm{P}_{6} \mathrm{O}_{18}\right)_{2}$, and $\mathrm{Cs}_{3} \mathrm{Cd}_{3} \mathrm{~V}\left(\mathrm{P}_{6} \mathrm{O}_{18}\right)_{2}$. United States: $\mathrm{N}$. p., 1996. Web.

doi:10.1134/1.170506.

[42] M. Bagieu-Beucher. Structure Cristalline du Polyphosphate de Manganese Trivalent $\mathrm{Mn}\left(\mathrm{PO}_{3}\right)_{3,}$ cta Cryst. B34, 1443-1446. (1978).

DOI :https://doi.org/10.1107/S0567740878005865

[43] M. T. Averbuch-Pouchot. Donnés cristallographiques sur quatre polyphosphates mixtes du type $\mathrm{BaM}^{\mathrm{II}}\left(\mathrm{PO}_{3}\right)_{4}$ pour $\mathrm{MII}=\mathrm{Mn}, \mathrm{Cd}, \mathrm{Ca}$ and Hg Crystal Data.J. Appl. Cryst.8, 389. (1975).

DOI :https://doi.org/10.1107/S002188987501076X

[44] M. Moutataouia, M. Lamire, M. Saadi and L. El Ammari,Dilithium manganese (II) catena-tetrakis(polyphosphate), $\quad \mathrm{Li}_{2} \mathrm{Mn}\left(\mathrm{PO}_{3}\right)_{4}$ Acta Crystallographica Section E. ISSN 1600-5368. 70) January 2014

DOI: 10.1107 / S1600536813032388

[45] Duc Tran Qui, I. Tordjman, Marie-Thérèse Averbuch, Gérard Bassi. Bulletin de Minéralogie Année 1970 93-4 pp. 413-420.

[46] B. Klinkeru, M. Jansen. Darstellung und Kristallstruktur von $\mathrm{Cs}_{2} \mathrm{Mn}\left(\mathrm{PO}_{3}\right)_{4}$, Journal of inorganic and general chemistry 670 102-108 (1989)

DOI :https://doi.org/10.1002/zaac.19895700109

[47] J. Rueff, O. Perez, A. Pautrat, N. Barrier, G. Hix, S. Hernot, H. Gourvès and P. Jaffrès. Structural Study of Hydrated/Dehydrated Manganese Thiophene-2, 5-diphosphonate Metal Organic Frameworks, $\mathrm{Mn}_{2}\left(\mathrm{O}_{3} \mathrm{P}-\mathrm{C}_{4} \mathrm{H}_{2} \mathrm{~S}-\mathrm{PO}_{3}\right) \cdot 2 \mathrm{H}_{2} \mathrm{O}$, Inorg. Chem, 51, 19, 10251-10261 (2012)

https://doi.org/10.1021/ic301187y
[48] I. Tordjman, D. Tranqui, A. Durif, M. T. Averbuch, Bulletin de Minéralogie Année 1968 91-3 pp. 242-246

[49] Persson, Kristin. Materials Data on LiMn(PO3)3 (SG:2) by Materials Project. United States: N. p., 2014. 1206004.

DOI:10.17188/1206004.

[50] A. Kapshuk, P. Nagornyi and O. Petrenko. Synthesis, IR spectra, and structures of double metaphosphates $\mathrm{MNi}\left(\mathrm{PO}_{3}\right)_{3}$ $(\mathrm{M}=\mathrm{Na}$ or $\mathrm{K})$, Crystallography Reports volume 45, pages206-209(2000) 